\title{
Scenarios of good anthropocenes in southern Africa
}

Article

Accepted Version

Hamann, M., Biggs, R., Pereira, L., Preiser, R., Hichert, T., Blanchard, R., Warrington Coetzee, H., King, N., Merrie, A., Nilsson, W., Odendaal, P., Poskitt, S., Sanchez Betancourt, D. and Ziervogel, G. (2020) Scenarios of good anthropocenes in southern Africa. Futures, 118. 102526. ISSN 0016-3287 doi: https://doi.org/10.1016/j.futures.2020.102526 Available at https://centaur.reading.ac.uk/88750/

It is advisable to refer to the publisher's version if you intend to cite from the work. See Guidance on citing.

To link to this article DOI: http://dx.doi.org/10.1016/j.futures.2020.102526

Publisher: Elsevier

All outputs in CentAUR are protected by Intellectual Property Rights law, including copyright law. Copyright and IPR is retained by the creators or other copyright holders. Terms and conditions for use of this material are defined in the End User Agreement.

\section{www.reading.ac.uk/centaur}

\section{CentAUR}


Central Archive at the University of Reading

Reading's research outputs online 


\section{Journal Pre-proof}

Scenarios of Good Anthropocenes in southern Africa

Maike Hamann, Reinette Biggs, Laura Pereira, Rika Preiser, Tanja Hichert, Ryan Blanchard, Hannelie Warrington Coetzee, Nicholas King, Andrew Merrie, Warren Nilsson, Pieter Odendaal, Samuel

Poskitt, Diana Sanchez Betancourt, Gina Ziervogel

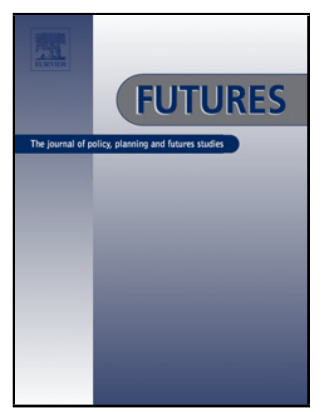

PII: S0016-3287(20)30016-1

DOI: $\quad$ https://doi.org/10.1016/j.futures.2020.102526

Reference: $\quad$ JFTR 102526

To appear in: $\quad$ Futures

Received Date: $\quad 16$ May 2019

Accepted Date: $\quad 20$ January 2020

Please cite this article as: Hamann M, Biggs R, Pereira L, Preiser R, Hichert T, Blanchard R, Warrington Coetzee H, King N, Merrie A, Nilsson W, Odendaal P, Poskitt S, Sanchez Betancourt D, Ziervogel G, Scenarios of Good Anthropocenes in southern Africa, Futures (2020), doi: https://doi.org/10.1016/j.futures.2020.102526

This is a PDF file of an article that has undergone enhancements after acceptance, such as the addition of a cover page and metadata, and formatting for readability, but it is not yet the definitive version of record. This version will undergo additional copyediting, typesetting and review before it is published in its final form, but we are providing this version to give early visibility of the article. Please note that, during the production process, errors may be discovered which could affect the content, and all legal disclaimers that apply to the journal pertain.

(C) 2019 Published by Elsevier. 


\title{
Scenarios of Good Anthropocenes in southern Africa
}

Maike Hamann ${ }^{1,2 *}$, Reinette Biggs ${ }^{2,3}$, Laura Pereira ${ }^{2,4}$, Rika Preiser $^{2}$, Tanja Hichert ${ }^{2}$, Ryan Blanchard $^{2,5}$, Hannelie Warrington Coetzee ${ }^{6}$, Nicholas King ${ }^{7}$, Andrew Merrie ${ }^{3}$, Warren Nilsson $^{8}$, Pieter Odendaal ${ }^{9}$, Samuel Poskitt ${ }^{10}$, Diana Sanchez Betancourt ${ }^{11}$, Gina Ziervogel ${ }^{12}$

\footnotetext{
${ }^{1}$ Humphrey School of Public Affairs, University of Minnesota, Minneapolis, MN 55455, USA

${ }^{2}$ Centre for Complex Systems in Transition, Stellenbosch University, Stellenbosch 7600, South Africa

${ }^{3}$ Stockholm Resilience Centre, Stockholm University, Stockholm SE-10691, Sweden

${ }^{4}$ Centre for Food Policy, City University of London, London EC1V 0HB, United Kingdom

${ }^{5}$ Council for Scientific and Industrial Research, Stellenbosch 7600, South Africa

${ }^{6}$ Independent visual artist and Animal, Plants and Environmental Sciences, University of the Witwatersrand, Braamfontein 2000, South Africa

${ }^{7}$ Research Unit for Environmental Science \& Management, North-West University, Potchefstroom 2520, South Africa

${ }^{8}$ Bertha Centre for Social Innovation, Graduate School of Business, University of Cape Town, Cape Town 8002, South Africa

${ }^{9}$ Queensland University of Technology, Brisbane 4001, Australia

${ }^{10}$ School of Agriculture, Policy and Development, University of Reading, Reading RG6 6AR, United Kingdom

${ }^{11}$ Open Streets Cape Town and Democracy, Governance and Service Delivery Programme, Human Sciences Research Council of South Africa, Cape Town 8000, South Africa

${ }^{12}$ African Climate and Development Initiative and Department of Environmental and Geographical Science, University of Cape Town, Cape Town 7700, South Africa
}

*corresponding author, contact details: Humphrey School of Public Affairs, University of Minnesota, $30119^{\text {th }}$ Ave S, Minneapolis, MN 55455, USA, maikehhamann@ gmail.com

\section{HIGHLIGHTS}

- Radical, positive scenarios of the future were created on the basis of already existing local-scale initiatives and innovations

- These futures were characterized by decentralized governance, localized production systems, connectedness, and empathy

- Business-as-usual socio-economic trajectories were abandoned across all futures, but the role of technology in everyday life varied

- The creative, participatory process inspired and encouraged an exploration of futures that included significant paradigm shifts

\begin{abstract}
In the rapidly changing and uncertain world of the Anthropocene, positive visions of the future could play a crucial role in catalysing deep social-ecological transformations to help guide humanity towards more sustainable and equitable futures. This paper presents the outcomes from a novel visioning process designed to elicit creative and inspirational future scenarios for
\end{abstract}


southern Africa. The approach based scenario development on "seeds of good Anthropocenes", i.e. existing initiatives or technologies that represent current, local-scale innovations for sustainability. A selection of seeds was used to create four distinct, positive visions in a participatory workshop process. Common themes that independently emerged in all four visions were i) decentralized governance and decision-making; ii) a strong emphasis on equity and empathy; iii) high levels of connectedness between people; and iv) a reinforced, respectful relationship with nature. The visions mainly differ in the extent of fusion between people and technology in everyday life, and how much nature plays a role in defining the human experience. The narratives presented here describe worlds that have undergone a more significant paradigm shift towards shared human values and stewardship of resources than is explored in most other ambient narratives for the region. These "Good Anthropocene" scenarios therefore demonstrate more radical, previously unimagined ways of thinking about sustainability futures on the African continent and beyond.

KEYWORDS: futures; visions; narratives; complexity; participatory process

\section{INTRODUCTION}

The Anthropocene is characterized by the unprecedented scale, speed and complexity of human influences on Earth, from widespread land cover changes and biodiversity loss to planetaryscale impacts on the oceans and atmospheric processes (Crutzen, 2002; McRae, Deinet, \& Freeman, 2017; Steffen et al., 2011; Steffen, Broadgate, Deutsch, Gaffney, \& Ludwig, 2015). At the same time, societies are rapidly changing and adapting to a globalizing, hyperconnected, and uncertain world (Adger, Barnett, Brown, Marshall, \& O'Brien, 2013; Hull \& Liu, 2018; O’Brien \& Leichenko, 2000). As a result, the Anthropocene continually presents new and diverse challenges, such as planetary tipping points, widening inequalities among people, and an increasing disconnect between humans and nature (Diffenbaugh \& Burke, 2019; Folke et al., 2011; Author et al., 2018; Piketty \& Saez, 2014; Steffen, Richardson, et al., 2015). Simultaneously, technological progress and new forms of organizing are opening up novel opportunities for addressing these challenges, with the potential to transform current trajectories for the planet towards more sustainable and equitable futures (Geels, Sovacool, Schwanen, \& Sorrell, 2017; Pearce, 2013; Steffen et al., 2018).

Creative visioning approaches can play a critical role in harnessing opportunities and dealing with the many uncertainties that typify the Anthropocene (Bennett et al., 2016). Visioning is important in decision-making, because visions of the future can help chart a course, direct actions, and enable policymakers to identify opportunities for facilitating change (Costanza, 2000; Yusoff \& Gabrys, 2011). Especially pertinent are positive visions or scenarios that counteract prevailing dystopian ideas of the future, since bleak future visions (such as "Mad Max" or "Fortress World") are not only demoralizing, but can in fact impede action and progress towards sustainable solutions by trapping society in reactive and defensive responses that aim to maintain the status quo (Morton, Rabinovich, Marshall, \& Bretschneider, 2011; 
O'Neill \& Nicholson-Cole, 2009). Furthermore, the critical engagement with dystopian ideas may amplify their perceived importance and make them seem more all-encompassing than they are, thereby masking the many alternative options that may exist (Gibson-Graham, 2006). In contrast, positive images and emotions encourage innovation and growth towards a brighter future (Cooperrider, 2001; Fredrickson, 2001), and can support the re-framing of change from a process of identifying problems and needs to, instead, identifying opportunities and assets (Kretzmann \& McKnight, 1993). As Fred Polak said in his seminal book The Image of the Future: "The rise and fall of images of the future precedes or accompanies the rise and fall of cultures. As long as a society's image is positive and flourishing, the flower of culture is in full bloom. Once the image begins to decay and lose its vitality, however, the culture does not long survive" (Polak, 1973:19). However, it is cognitively challenging to think about the future in truly new, creative, and radical ways that move beyond not only dystopic visions, but also business-as-usual projections of the present into the future (Gilbert \& Wilson, 2007; Liberman, Sagristano, \& Trope, 2002; Loewenstein, O’Donoghue, \& Rabin, 2003; Pang, 2010).

The "Seeds of Good Anthropocenes" (SOGA) initiative is one such creative approach to exploring more optimistic societal and planetary trajectories. This initiative specifically aims to solicit, explore, and develop a suite of alternative visions for "Good Anthropocenes" - i.e. positive futures that are socially and ecologically desirable, just, and sustainable (Bennett et al., 2016; Author et al., 2017; Author et al., 2017). These visions are based on "seeds" of positive futures that already exist in the present. The seeds are mostly small-scale, experimental projects, initiatives, and organizations that employ new ways of thinking or doing, and exist at the margin of current society. Seeds can be new social institutions, technologies, or frameworks for understanding the world that are not yet mainstream, but at the local scale have been shown to improve livelihoods and sustainability outcomes. In one way, these seeds represent not yet fully developed "strengths" in the system, which - if cultivated - can positively reinforce community development (Peterson \& Seligman, 2003; Seligman \& Csikszentmihalyi, 2000). Ultimately, should such seeds be nurtured and grown, they are deemed capable of shifting the Anthropocene trajectory towards a better future for people and planet. Information on seed projects has been collected through a number of online surveys and international workshops, and catalogued on the SOGA website and database (www.goodanthropocenes.net). These seeds represent a real, tangible, and meaningful starting point for creating visions of good Anthropocenes. They also embody the necessary diversity, flexibility, and range to explore what different visions might look like for people in different parts of the world (Bennett et al., 2016).

This paper analyses the outcomes from the first workshop to generate scenarios or visions of radically alternative "good" futures based on a selection of seeds. The workshop focussed specifically on developing a set of visions for the southern African region. Typically, scenario exercises follow a deductive method using techniques of prioritization to construct the development of three or four qualitative narratives or storylines that are based on critical uncertainties, and which involve different trends and key assumptions. These plausible futures are often mapped out along two main axes of uncertainty, to arrive at a number of distinct, alternative future visions (Oteros-Rozas, Martin-Lopez, et al., 2015; Peterson, Cumming, \& 
Carpenter, 2003). The process used here instead draws heavily on the Mānoa method of scenario planning (Bishop, Hines, \& Collins, 2007; Schultz, 2015), which is an inductive approach based on the exploration of the impacts and interactions of emerging issues of change or "weak signals" (in this case, seeds), and is designed to maximize differences from the present. The facilitated visioning process, undertaken with a diverse group of participants at a workshop in Cape Town, South Africa, is described in detail by Author et al. (2018). Here, the process is briefly outlined, and the resulting four positive visions for the Anthropocene in southern Africa are introduced. Common and divergent themes across the four visions are analysed, and the scenarios are compared to other well-known narratives for the region. Finally, the potential contribution of this approach to scenario development is explored.

\section{METHODS}

The objective of the exercise was to generate visions of potential Good Anthropocenes in southern Africa from a set of seeds - see Author et al. (2018) for a full account of the methods. The following sections provide an overview of the three main phases of the process: First, the seeds that were to form the foundation for the scenarios were selected. Secondly, four diverse groups of participants imagined how these seed initiatives would interact if they were no longer fringe activities or products, but widely distributed and mainstreamed "ways of doing". Based on these seed interactions, groups created the first outlines of their future vision. In the final phase, each group expanded their vision and identified potential pathways that link the present to the future (Fig. 1).

\subsection{Seed selection}

Potential seeds from the SOGA database (www.goodanthropocenes.net) were screened for suitability. To be included in this process, seeds needed to be of southern African origin, or they needed to represent a globally relevant technological innovation (such as artificial meat). The final list of seeds was selected to maximise diversity between the seed types, as well as the potential for including a participant in our workshop who could represent a seed initiative. From this final list, highly divergent seeds were grouped into sets of three, made up of one "global technology" seed and two southern African seeds. For a complete list and brief descriptions of the selected seeds, please refer to Appendix A.

\subsection{Imagining seeds in the future}

Similar to the seed selection, participants were chosen with the aim of maximizing diversity and divergence. Part of the innovative experimentation of this process was the deliberate inclusion of seed "representatives" in the participant pool, i.e. people that were in some way connected to a seed, either through direct involvement in a seed project or due to detailed knowledge of the initiative or technology. Beyond the seed representatives, the groups comprised a mix of scientists, practitioners, and artists. This diversity of skills and knowledge was sought to enhance the creativity and novelty of the envisioned futures (Clammer, 2014). The participants were identified through the professional network of the workshop organizers 
and the SOGA initiative, as well as further snowball sampling among invited participants. In the end, the workshop included four groups of between 5 and 6 participants, plus a facilitator. The intention was that participants work in the same groups throughout the process, but switching teams was possible if called for by group dynamics.

Each group was given one set of three seeds to use in creating their vision. First, the likely impacts of the seeds in a future world needed to be identified. To achieve this, seeds had to be imagined in their mature condition, i.e. no longer as a marginal activity or initiative, but as the mainstream way of doing things. What if, for example, artificial meat was the main source of protein in people's diets? The groups were tasked with constructing a Futures Wheel around each seed in its mature condition. In a Futures Wheel exercise, primary, secondary and tertiary impacts and consequences of a central event or idea (i.e. the mature seed) are explored (Glenn, 2009).

In a second step, the groups went on to create cross-impact matrices using their seeds. This is a thought exercise which allows participants to discuss and note the impact that one seed and its implications may have on another, and vice versa. The interactions identified with the help of cross-impact matrices were then mapped onto the group's Futures Wheels, by drawing connections between impacts across the three different wheels (Fig. 2). These exercises allowed the groups to highlight conflicts and/or synergies between the seeds, which contributed towards forming a more comprehensive picture of a potential future containing complexities and ambiguities. At the end of this process, each group presented their newly-developed scenario outline by means of one artistic image (using any medium), three fictional statistics and a social commentary or news headline.

\subsection{Creating narratives and identifying pathways}

To go from scenario outlines to more fully formed narratives, groups spent time refining and envisioning their futures in more detail. Throughout all the exercises and group discussions, participants were encouraged to make use of the STEEP-V and Verge brainstorming tools. STEEP-V helps explicitly to consider social, technical, economic, environmental, political, and value impacts of future changes. Verge adds an ethnographic aspect and prompts participants to think carefully about the ways in which people relate to one another and their environment in future scenarios (Lum, 2015). This is achieved by asking questions of the participants, e.g. in this future world, how do we define things? How do we connect to one another? What do we consume, or throw away?

After spending time envisioning their futures in more detail and expanding their narratives, the groups used the Three Horizons framework (Curry \& Hodgson, 2008; Sharpe, 2015) to connect their future visions to the present. In this case the Three Horizons framework was used as a graphical tool to encourage participants to identify dominant system components and paradigms in the present ( $1^{\text {st }}$ Horizon) that would need to change or disappear if a "good Anthropocene" future ( $3^{\text {rd }}$ Horizon) were to be achieved (Fig. 3). The seeds form part of the early $3^{\text {rd }}$ Horizon, and their maturing and mainstreaming is part of the trajectory that becomes the positive future. Beyond the seeds, the Three Horizons helped groups identify other novel trends, ideas and developments that would need to become dominant in their positive future 
visions. The tool allowed for an exploration of clashes and synergies between the waning and emerging paradigms in the transition period ( $2^{\text {nd }}$ Horizon). The Three Horizons encouraged participants to think through potential pathways of change, and informed their developing scenario narratives.

The final part of the workshop saw each group share their scenario with the rest of the participants. There had been no instructions on how to present the scenarios, and each group independently chose a highly creative role-playing approach, using acting, props, dancing and lighting. Following this sharing of visions, the participants were led through a collective reflection session, in which they discussed their insights and learnings with each other.

\section{RESULTS}

This section first describes the different scenarios that were created, and then outlines common themes and key divergences that emerged. Finally, the pathways that link the futures to the present are explored.

\subsection{Four positive visions for the future of southern Africa}

The visioning process resulted in four different scenarios. The descriptions below are based on the official workshop report (CST-GRAID, 2017), and draw heavily on the scenario narratives captured by each group's facilitator immediately following the 3-day workshop, with input from the group members. The workshop and resulting scenarios are also summarized in a whiteboard video that can be viewed online (CST, 2017).

\subsubsection{Rhiz(h)ome}

Summary: In this scenario, the emphasis is on highly decentralized governance and business, epitomized by a myriad of interconnected, small, and green cities across southern Africa. An empowered citizenry places value on fairness, knowledge-sharing, learning, self-fulfilment and environmental stewardship. Technology has enabled highly efficient, localized production processes, as well as a more transparent and diversified exchange of goods and services.

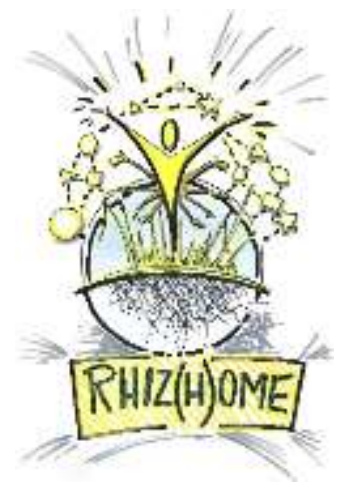

This world has emerged through a radical restructuring of the social, political and economic institutions of the southern African region, echoing changes around the world. For one, there has been a fundamental shift in the nature and meaning of work. The alienating notion of labour has been replaced by an emphasis on societal contribution and opportunities for self-fulfilment, expression and agency. The economy has become process and service-based, rather than output-based. Society has ended its obsession with material goods. Businesses now specialize in creating opportunities for human fulfilment and the generation and sharing of knowledge.

Technology has enabled high levels of direct participation in decision-making at multiple scales. This allows communities and economies to be local and deeply context sensitive, and at the same time richly interconnected globally. Collaboration and partnership inform the 
underlying societal norms. In the Rhiz(h)ome world, access to key resources, especially food, healthcare, housing, water, and energy is equitable and context-sensitive. The Earth is seen as a collective resource and base for prosperity, and land ownership has been fundamentally reimagined as stewardship.

Awareness, understanding and respect for nature has greatly increased; people are in tune with their local environment and the cycles of nature. Cities are green; environmentally sensitive building technology is integrated with large, diverse urban green spaces. Highly interconnected smaller cities have replaced the development of further mega-cities, and the distinction between rural and urban is increasingly blurred. Technology has greatly increased the production of environmentally friendly, multi-purpose goods. It has also enabled most food and goods to be produced locally, drastically reducing transportation and waste.

Environmental resources are largely governed through non-governmental organizations, cooperatives and other citizen-based coalitions, where local contextual knowledge is highly valued. There has been a rise in new, ecologically-informed governance units such as "bioregions", as well as virtual communities. Although governance is much more decentralized, appropriate larger-scale governance structures have been maintained to help redistribute resources, govern the commons, and mediate conflicts of interest. Regional integration of African communities and countries has consequently strengthened, despite a decline in the importance of the nation state.

The shift in governance structures and the economy was facilitated by technological developments, especially blockchain technology that enables decentralized, self-managed, and communally held records of ownership and exchange. This has enabled many previously voluntary activities and participation in citizen and governance structures to be appropriately rewarded.

This world is fundamentally marked by an empowered citizenry, committed to participation, fairness and justice. The collective fear that characterised previous eras has been replaced by a focus on empathy, reducing separation between races, genders, languages and cultures. Difference is valued and respected, and there is formal recourse for marginalised voices. There is an openness, awareness and curiosity about the wider world and human nature. In the Rhiz(h)ome world, imaginative capacities are valued and supported, and new futures are continuously explored and cultivated.

\subsubsection{Post Exodus}

Summary: This scenario describes a world that has gone through a severe collapse, in the wake of which part of humanity flees the Earth to extra-terrestrial colonies. After this exodus, the remaining humans re-build their communities with a focus on small, local production systems and collective sharing of experiences and decision-making. The main aim is to continually improve empathetic connections to each other and the planet.

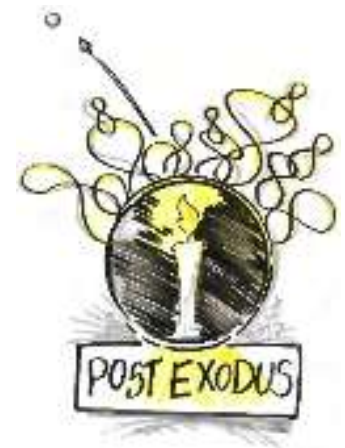

In the near future, natural resource scarcity and socio-economic inequalities lead to an increasingly polarized society. Social unrest and backlash against the elite becomes more and more common. In an effort to counter globalization forces, communities start to experiment 
with localized, direct production systems using technologies like 3D-printing and diverse, nonmonetary currency systems. Education becomes less centralized, and spreads widely via virtual learning platforms. In the wake of strong community development and their increasing independence from central governments, the top-down institutional approach to problem solving weakens, and civil society rises as a powerful force. Monopolies fall, and brands lose their appeal. As the global economic system crumbles, in conjunction with increasing resource scarcity and environmental degradation, the socio-economic elite recognizes the limitations of Earth and invests heavily in space travel and planetary colonization, as well as gene editing technology to eradicate diseases and prolong life. In the elite's pursuit of their own advancement, the notion of the public interest dies. Competition over resources like water and food ultimately culminates in great wars and the flight of the elite to new extra-terrestrial colonies.

Those who remain after the exodus, Earth's 'post-humans', are left with an exploited planet, where resources are scarce and old institutional systems have been destroyed. However, the pre-exodus successes in gene therapy mean that humans have evolved to live healthy and very long lives. People in southern Africa now reside in thousands of small, distributed, local communities (rather than large cities) and focus on building localized, closed-loop production and consumption systems where there is no waste. As a result, natural resources slowly recover from the previous era's overexploitation, and the region is characterized by thriving, enterprising village ecosystems with strong African identities.

Advancements in information and communications technology allow for these village ecosystems to be digitally connected to each other across the globe, forming truly 'glocal' communities. People meet, interact and share knowledge and experiences in 'The Collective', a physical and virtual community street space, where cultural and artistic self-expression is highly valued. The core objective of The Collective is to build an understanding between individuals, cultures, and contexts, to encourage empathy and humility. A newly developed, global language allows people across the world to participate in The Collective.

Decisions are made through a system of deep dialogues, which are held through digital and physical platforms to enable a fully participatory process. These collective decision-making processes are assisted by situational leaders that provide particular expertise and knowledge for specific situations. Such a globally participatory deep dialogue is used, for example, to discuss the need of limiting post-human life spans to 350 years, based on the belief that the cycle of life and death should not be broken by immortality. There are no centralized leadership structures, or even legal institutions. Law is a genuine social contract, and prisons do not exist. Conflicts are addressed through deep dialogue and reciprocal understanding. As a whole, society is slowly moving towards a collective consciousness, brought about by extensive knowledge sharing and profound empathetic engagement. 


\subsubsection{Demos42 Ubuntunse}

Summary: This scenario is dominated by the emergence of an artificial super-intelligence called Demos42, which connects and guides humanity in the spirit of togetherness and radical openness. Infrastructure, just like society as a whole, has become fluid and ever-shifting, responding to needs in real-time. In this world, food is a significant part of the social fabric, connecting not just people with each other in gastro-gardens, but also connecting the present to the past.

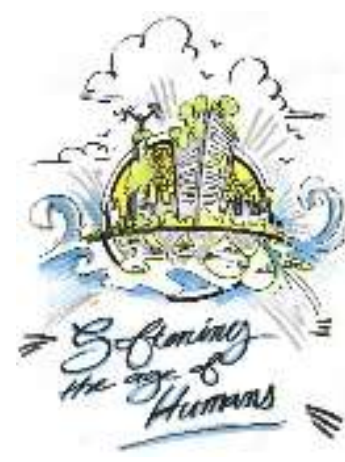

It was a day to remember - the day that a spark in the midst of crisis became Demos42, an artificial intelligence (AI) that connects and guides humanity, based on the principles of Ubuntunse. This philosophy understands humans as part of a bigger whole, and that everyone has a responsibility to contribute to the common good. Demos42 emerged and became the antidote to false data by harnessing humanity's collective thinking to create a nurturing superintelligence. Demos42 enabled an era of radical transparency where the distinction between leaders and followers ceased to exist. Power and expertise are diffuse, and due to Demos42's demilitarization process, there are no more borders, no nation states, no passports, and no hierarchical governance system. Meetings are convened when there are issues to discuss, and Demos42 ensures that people with the necessary expertise are present. S(h)e intervenes with data, humour, and knowledge, if these meetings do not uphold the ethos of our collective, ungendered society.

The developments in AI allowed for a reconceptualization of the world to embrace the spirit of water: its formless, shapeless, adaptive and fluid nature. As a result, infrastructure becomes fluid, a complete reversal of the (un)civil engineering from the past that was built for functionality and not for humanity; it had no feeling, no soul, no ability to interact with the humans who were supposed to use it. Previously, hard, straight-line infrastructure was built for a single purpose, and roads, buildings, stadia were meant to exist in that form for decades. In this world, the advent of $\mathrm{AI}$ and especially 4D printing ('intelligent' 3D printing), allowed a rethink of this static approach. Drawing inspiration from nature, 4D components of infrastructure are printed and can be used many times in many different forms as they literally 'shape-shift' according to needs across time and space. These components are reminiscent of intelligent Lego blocks (many of which are self-energizing using solar energy), which construct themselves into built forms as needed. For example, these blocks may form an office building during the day, a gym before and after office hours, or a sports stadium just for match-day. The multipurpose usefulness of infrastructure, coupled with a sharing economy, means that much needed space and time is freed up for other purposes and activities - especially for communal projects such as gastro-gardens, renewable energy generation and water storage.

In the Demos42 world, food nurtures social relations. Food production and consumption is guided by the concept of a 'slow-food' nostalgia that is progressive, but recognizes the knowledge of the past. Food is grown in vertical and horizontal gastro-gardens from which people gather edible plants and insects. Everyone has the ability to grow and prepare food through communal ownership of space and downloadable knowledge from Demos42, and excess produce is stored underground using the knowledge of ancestors. The completely decentralized nature of technology, fluidity of infrastructure and reduced space requirements 
for food production mean that communities continually form and disperse across southern Africa, co-existing in mutual respect with other species in the region.

\subsubsection{Radical TransLocal}

Summary: This scenario sees a return to community-driven decisionmaking based on indigenous knowledge and a deep connection to Mother Earth. Consumption is guided by a machine learning system that accounts for the full ecological cost of every choice, and food production has been revolutionized by personal artificial meat processors. Society embraces learning and artful expression, and strives to exist in balance with nature.

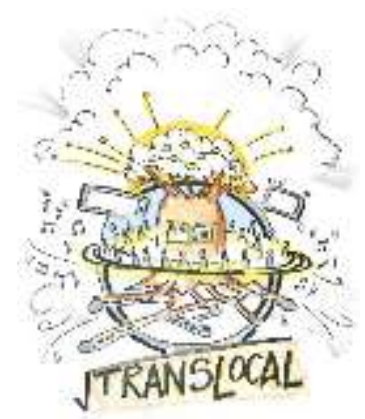

It is unclear how it all started, but in this world, every tree has become a sacred beacon of hope where people gather, debate, govern, make decisions, and - most importantly - teach and learn. What started as community meeting under a tree eventually became an eco-centric communitybased movement that embraces social and environmental issues equally. Indigenous knowledge systems have been re-discovered as a source of connectedness to nature and each other. Going back to the roots of humanity was a simple yet radical notion that captured the hearts of all across the globe.

This form of government means that every citizen's opinion matters and is heard. Every individual can participate in decision-making though direct virtual voting, and by joining the discussions at the Tree. This system acknowledges stakeholder-based property rights, which increase community buy-in and investments in local assets and ecosystem services, as well as ethical modes of production and consumption. The widespread adoption of edu-tourism initiatives is one result of this community-based natural resource management. In addition, there has been a reduction in economic migration, allowing people to move around between rural villages and cities because they choose to do so freely, not because of socio-economic hardship.

All decisions are bound by a deep commitment to the protection and health of the environment. There is an understanding that the Earth nurtures, heals, provides and supports. To assist individuals in making Earth-conscious decisions, VERITAS was developed. VERITAS - the Virtual Eco-centric Redistributive Index Tax Adaptive System - is an artificial intelligence that accounts for the full ecological cost of all the products that a person uses every day, and provides opportunities to improve one's "eco-status". In this way, consumption is kept in balance with what can be provided by nature.

Technology facilitated this movement by improving food production systems. Techno-food and the iMeat3000 (an artificial meat processor) changed the way the world interacted with nature in very much the same way that the smartphone of the 21 st century changed the way humans communicated. This led to a decrease in industrial food production and waste, and also to an expansion of new kinds of designed health foods, such as cauli-fish@. VERITAS assists in aligning every individual's diet with their physical and mental needs, and in balance with the needs of the non-human inhabitants on Earth.

Technological advancements also freed people from offices, workstations and mundane jobs. Individuals learn diverse skills from a young age and are encouraged to pursue their passions. Education is freed from the concept of educational institutions. Instead, every aspect of life is 
considered to be an opportunity for active, adaptive learning. Technologies and experiments enable people to develop their own agency by educating themselves and each other in real time, as part of everyday community living. But every citizen is also expected to assist the community in a variety of ways, exchanging skills and services as part of the hybrid economy that characterizes this world. Art is a significant and ubiquitous medium through which people communicate with and relate to one another and the more-than-human world.

3.2 Commonalities, divergences, and pathways to the future

The four visions created by the workshop participants shared a number of common themes, but also exhibited unique characteristics and trends - especially in how the positive futures were achieved, i.e. in the pathways of change.

\subsubsection{Common themes}

One of the main features in all four visions is the decentralization of systems and governance (Table 1). Local communities organize their daily lives, and there is less emphasis on central institutions and government. However, the Rhiz(h)ome scenario balances this with certain institutions that are centralized to deal with issues of coordination at larger scales, such as the governance of common-pool resources. The overall decentralization of power is accompanied by collective, participatory and localized decision-making, which - in the case of these scenarios - reduces gender and other socio-economic inequalities.

Tightly linked to this focus on localized governance is the general emphasis on connectedness in all four scenarios. The worlds are characterized by high levels of connectivity between people and communities, but also between people and nature. These connections are often enabled through advanced technology (like virtual meeting places as described in Post Exodus, or the artificial intelligence that connects all of society in Demos42 Ubuntunse), but also go beyond the technological. The scenarios produced in this visioning exercise are characterized by deeply empathetic human relationships and an almost spiritual reconnection to the biosphere.

In part, this respect for nature is expressed by the change from a consumer culture towards a post-consumerist ethic, where products and services are mostly produced and consumed locally in ways that don't transgress planetary and local environmental boundaries. Closed-loop production and waste schemes dominate. Taking this ideal even further, the Radical TransLocal scenario describes a personalized algorithm-based management system that guides consumer choices towards sustainable resource use options. Overall, the scenarios illustrate a shift away from anthropocentric worldviews towards more eco-centric attitudes and behaviours. In essence, the relationship between humans and the planet becomes about stewardship, rather than exploitation.

In addition, the four scenarios describe worlds in which the economy is a shared social process, and money is only one of many currencies of exchange. The common good is highly valued, and the nature of work itself is transformed: jobs are now self-actualizing activities that support the community, and education is no longer focused on producing "workers", but rather 
productive and fulfilled members of society, encouraging collaboration and cooperation over individualism and competition.

\subsubsection{Divergences and risks}

The visions differed in their conception of future landscapes, with Demos42 Ubuntunse describing a highly urbanized population living in large cities, while nature reclaims the world outside of these urban hubs. The other three scenarios describe situations in which smaller urban centers and communities are distributed across the landscape, without the presence of megacities. Two of the scenarios, Post Exodus and Radical TransLocal, envision the (re)connection of humanity to nature as a fundamental shift in what it means to be human. In the Rhiz(h)ome and Demos42 Ubuntunse scenarios, nature is more of a source of inspiration and fundamental to the design of how cities and communities work. In addition, the arts play a central role in cultivating the relationship between humans and nature in the Radical TransLocal world.

Furthermore, the scenarios differ in the extent to which technology becomes an integral part of everyday life, from the almost complete merging of technology and human experience in Demos42 Ubuntunse, to the more restrained and practical-oriented use of technology in the Rhiz(h)ome scenario. Other differences are summarized in Table 2.

While all scenarios have a strong focus on decentralized decision-making, one of the greatest risks of decentralized systems of governance is the potential creation of fascist niches. Mostly, the scenarios deal with this challenge through technology-enabled radical openness and beyond-local transparency and accountability. But technology can come at a price. In all scenarios, a strong reliance on technology has the potential to manipulate people and increase existing social and economic inequalities. In the Post Exodus scenario, extreme longevity enabled by gene therapy poses a challenge to the ethos of respecting the cycle of life. In this case, the challenge is overcome via a process of collective, highly participatory decisionmaking.

A key finding across the scenarios is that there is generally little discussion on how to govern the diverse pathways that could emerge from rapid technological change. Nowhere is the risk of rapid technological change as apparent as in the Demos42 Ubuntunse scenario, which relies on the benevolence of an artificial intelligence. Since artificial intelligence had emerged from a rapid investment in internet and communication technologies (ICT) on the African continent, (s)he was imbued with a spirit of Ubuntu or 'one-ness' that was benign. The risk of having a malign artificial intelligence was discussed within the group, and was considered a major threat to a positive vision. The idea that the emergence of artificial superintelligence will trigger runaway technological growth resulting in unprecedented change in human civilization remains science fiction, but may be increasingly plausible (Kurzweil, 2005). Not engaging with the possible ramifications of developments in artificial intelligence across multiple domains of human existence remains a gap in many environmental scenario planning processes.

\subsubsection{Pathways to change}

The Three Horizons framework proved to be a powerful tool for linking the four visions to potential pathways towards achieving each future. Whilst the scenarios all seem quite radical 
and maybe even implausible, working through the Three Horizons framework enabled each of the groups to discuss what would need to happen in order to achieve the future that had been envisioned, and especially what turning points occurred in the second horizon in order for the dominant way of doing things (first horizon) to break down and the marginal 'seeds' to grow more powerful (third horizon) (Fig. 4).

In the case of Demos42 Ubuntunse, there was a critical turning point when the 'spark' that awakened the super-intelligence occurred. Similarly, the Post Exodus scenario details a number of key events, such as breakthroughs in gene therapy that significantly reduce the prevalence of disease and increase longevity in humans. However, such turning points are not enough without the simultaneous growth of other "seeds". The positive future of Demos42 Ubuntunse required, for instance, the development of solar-powered 3D printed cells that could become 'smart' and adapt to changing conditions, as well as a rewilding of rural landscapes. Often, $2^{\text {nd }}$ horizon events were crucial in acting as early adopters or catalysts for emerging change. For example, in the Radical TransLocal world, initiatives like the Sustainable Development Goals (SDGs) and Aichi Biodiversity Targets created entry points for the adoption of an accounting system that tracks personal resource use in real time (VERITAS).

As some seeds grow and establish themselves, much of the existing status quo needs to fade away. The most difficult aspect of the Three Horizon exercise was to imagine how prevailing power structures and entrenched interests are broken down. In the Post Exodus scenario, this process was helped along by the flight of the elites from the planet after times of great conflict and collapse. In the future of Demos42 Ubuntunse, it took a decline in industrial jobs and financial collapse alongside the development of AI to spark the transition onto a more positive trajectory. In Radical TransLocal's world, the decline of industrial agriculture was spurred on by land reform, changes in property rights, and widely-adopted land stewardship practices, as well as technological advancements in the food system (such as artificial meat). Often, these transitions are far from smooth, but some small existing gains that could be implemented right now were also identified. These include, for example: a common passport for the southern African region (similar to the European Union) to start breaking down borders; a focussed investment in decentralised, community-based natural resource management and communityowned renewable energy projects; and a reclamation of public space and greening of cities with edible plants.

\section{DISCUSSION}

The visioning process described here produced four distinct narratives for southern Africa that shared many commonalities, and ventured into the realm of science fiction. In this way, they differ markedly from scenarios produced in more conventional processes, where storylines are usually restricted by the "possible, but plausible" principle. In addition, most scenario planning exercises aim to produce three to four distinct narratives that result from differences in key drivers of change (Oteros-Rozas et al., 2015), often using a quadrant with two axes of divergence, i.e. the $2 \times 2$ matrix approach (Curry \& Schultz, 2009). The Millennium Ecosystem Assessment, for example, produced four scenarios that differed in two main ways: whether environmental management policies were proactive or reactive, and the degree of connectedness among and within institutions (i.e. towards more globalization vs. more 
regionalization) (Cork et al., 2005). While the $2 \times 2$ matrix approach often leads to comparable storylines being developed across multiple different scenario exercises, they may lack imagination in terms of how these narratives capture diversity and complexity, and have been described as an imaginative flatland (Curry \& Schultz 2009).

Unlike more common deductive scenario planning exercises, the process described here was designed to be more inductive and creative. Rather than differentiating along key drivers of change, the visioning process anchored the storylines in existing seeds initiatives, but provided free reign in all other aspects. Common features, as well as differences, therefore emerged independently among the groups. In particular, this more inductive and creative approach stimulated a broad range of thinking and imagination with regards to what could be possible in the future. The performative element at the end then brought the imagined visions to life, allowing participants to understand what it might mean to live in these futures. Many of the participants later reflected that this approach had encouraged them to think 'outside the box', tapping into a creative part of their imagination that they would not normally use (Author, 2018). Although these narratives are more difficult to code into factors that could inform quantitative models, their focus on affective knowing and ability to deal with complexity, emergence, and diversity offer a powerful alternative to the business-as-usual way of developing scenarios for the Anthropocene. The benefits of this visioning approach have been recognized by the IPBES expert group on scenarios and models (Lundquist et al., 2017).

\subsection{Key features}

The most striking commonality between all four scenarios was a decentralized governance system and highly participatory, citizen-led, and equitable decision-making. In addition, technology acted as a strong connector between people, and all scenarios describe a deep reconnection of humanity to the biosphere. It is noteworthy that these features were seen as important aspects of positive futures by all the groups that took part in the workshop. However, there were differences between the scenarios in the extent to which technology infused everyday life, as well as the ways in which the reconnection to nature is manifested. In the Rhiz(h)ome and Demos42 Ubuntunse scenarios, nature is mimicked and used for inspiration. In the Post Exodus and Radical TransLocal scenarios, the connection to nature is more deeply embedded in the ways people define themselves and their role in the world.

Interestingly, all the visions created in this exercise include examples of the basic innovations that have been put forward as the foundation for the next Kondratieff cycle (or K-wave). The $\mathrm{K}$-wave concept refers to 50-60 year cycles of innovation clusters and economic prosperity that have been used to explain patterns in Western economies for the last 200 years (Korotayev, Zinkina, \& Bogevolnov, 2011; Linstone \& Devezas, 2012). The $5^{\text {th }}$ and current cycle is characterized by innovations in information and telecommunications, though some argue that the early stages of the $6^{\text {th }}$ cycle have already begun. This next cycle will be driven by advances in health as well as bio- and nanotechnology, including a more holistic understanding of health and its various components (physical, mental, social, ecological and spiritual) (Nefiodow \& Nefiodow, 2014). In line with this theory, the scenarios outlined here describe worlds in which the connections between people, as well as between people and nature, are restored and 
enhanced, contributing to improved well-being. Bio- and nanotechnological innovations were included in the form of advanced gene therapy, artificial meat production, and shape-shifting building blocks.

The scenarios also open a doorway to more fully understanding the long-term dynamics and potentials of the social innovation process (Mulgan, 2006). Despite its early emphasis on discrete solutions to specific challenges, the social innovation conversation has begun to take a more systemic slant (Author, 2019). Unger (2015) argues that social innovation is, at heart, an attempt to elevate the power of localized, often small-scale, agency in order to catalyse dramatically different global futures. And indeed, this dynamic played out in the visioning process: The initiatives and innovations chosen as seeds were relatively localized and smallscale, and not especially dramatic. Yet they played off of each other and revealed surprising potential to provoke radical scenarios. And though dissimilar in form, the scenarios expressed remarkably similar values and paradigms. This may indicate that the world's current social innovations are much more radical and aligned than they appear. Shifting from a problemcentric approach to an appreciative or strengths-based seeds approach may therefore help unlock the deeper system potentials inherent in even the least visibly transformative social innovations.

\subsection{Comparison to other scenarios}

Many different scenario narratives have been created for Africa over the years, from very localized scenarios for place-based futures, to scenarios that span the entire continent (Author et al., 2018). One striking difference between the Good Anthropocene visions and previous narratives is the level of creativity and breadth of possibilities that they contain. This can be observed in the Demos42 Ubuntunse scenario, which considered the possibility of a benevolent artificial intelligence that connects all life, or in the Post Exodus scenario that explored the use of gene-editing to radically extend the longevity of human life. This sits in stark contrast with scenarios built through more deductive and policy-oriented approaches, such as the CCAFS East Africa scenarios (Vervoort et al., 2013).

Similarly, certain trends that commonly feature in previous scenarios are not prevalent in the Good Anthropocene visions. Globalization, for example, is not a strong driving force in any of the visions described here, and instead the focus is much more on regional and local production and consumption patterns. In this regard, the visions are most closely aligned with the narratives explored in the "Great Transitions" scenario family or archetype (Gallopin, Hammond, Raskin, \& Swart, 1997; Hunt et al., 2012). Scenarios within an archetype share a similar storyline or logic (van Vuuren, Kok, Girod, Lucas, \& de Vries, 2012). Within the Great Transitions archetype, there are two different dominant narratives, i.e. the "EcoCommunalism" and the "New Sustainability Paradigm" scenarios. The former envisions a world characterized by a strong bio-regional and local focus, with many smaller, self-reliant, sustainable and autonomous communities that practice face-to-face democracy (Raskin et al., 2002). The Post Exodus and Radical TransLocal scenarios share many characteristics with the Eco-Communalism narratives. Other well-known scenarios that fall into this category are the "Adapting Mosaic" narrative of the Millennium Ecosystem Assessment (MA) (Cork et al., 
2005), and the B2 storyline of the IPCC emissions scenarios (IPCC, 2000). In contrast, Demos42 Ubuntunse and Rhiz(h)ome are more similar to the New Sustainability Paradigm group of scenarios, which envision a more globalized, cosmopolitan, culturally cross-fertilized, and economically connected society than the Eco-Communalism storylines (Raskin et al., 2002). The "Techno garden" scenario of the MA and B1 of the IPCC emissions scenarios fall within this category (Hunt et al., 2012). However, in all these cases, the Good Anthropocene scenarios go much further in envisioning more distributed, place-based, and equitable decisionmaking structures that are nevertheless highly connected to regional and global communities, thus countering the pitfalls of overly localized governance of resources while still preserving local identities.

More recently, scenarios produced for the Global Environmental Outlook (GEO-6) regional assessment for Africa include narratives based on decentralised decision-making and governance, with an orientation either towards global ("Helping Hands") or African ("All In Together") trade and production (UNEP, 2016). The Good Anthropocene scenarios exhibit similarities with both of those narratives, though the GEO-6 scenarios are much more constrained by current trends and possibilities. Similarly, the vision put forth by Agenda 2063 for Africa (African Union Commission, 2015) is based on extrapolations of past and existing continental initiatives for sustainable growth and development, without significantly pushing the boundaries of what is possible in a truly uncertain and exponentially changing Anthropocene. The 2063 vision is focused on strengthening Africa's role in a globalizing world, and aims to achieve the SDGs mainly through standard economic growth. The 2063 vision is heavily embedded within conventional technological trends and does not emphasise the rich bio-cultural diversity of the continent. In contrast, the Good Anthropocene visions described here achieve the SDGs by focusing on circular economies with equitable sharing of resources and alternative (non-monetary) exchanges of goods and services. These narratives describe worlds that have undergone a much more significant paradigm shift towards shared human values and stewardship of resources than is explored in most of the other ambient narratives for Africa and the globe. The visions emerging from this process therefore demonstrate more radical, unimagined ways of thinking about sustainability futures on the African continent (and globally), that go beyond what can be captured in archetypes or traditional planning processes.

\subsection{Limitations and learnings}

As outlined by Author et al. (2018), the outcomes of this approach to develop scenarios of Good Anthropocenes are highly dependent on the original selection of seed initiatives that form the basis for the scenarios. For example, advances in technology played an important part in all four scenarios, which is likely due to the purposeful inclusion of seeds that represent technological innovations. Future iterations of this approach may aim to experiment with different "starting" seeds, to understand how much these initial conditions influence the kinds of scenarios that are created. However, the objectives of the visioning exercise should guide the seed selection. It might not matter much if the content of the scenarios is of secondary importance, and the focus is on the process and bringing people together to envision positive change. On the other hand, it might be crucial to include certain seeds and their representatives 
in this process, if the goal is to enhance cooperation and networking among certain stakeholders.

Another key feature of the scenarios was that there was a certain degree of convergence in the storylines, with shared themes of decentralized governance, localized production and consumption cycles, and strong connections to nature. To some extent, this is to be expected since the Mānoa method employed here is not designed to explore a wide range of possible and divergent futures. Instead, its goal is to maximize difference from the present (Curry \& Schultz, 2009). If the goal had been to explore as vast a future space as possible - which may be desirable when different policy options need to be considered in situations of high uncertainty - one option might be to choose more orthogonally divergent seeds to begin with, or a different method altogether. Alternatively, a combination of methods may help diversify the outcomes and examine key drivers of change. For example, Falardeau et al. (2018) introduced axes of uncertainty into the "Mānoa plus seeds" approach, and found that it helped to create differences in the scenarios. However, strong similarities in the storylines remained, which the authors attribute to shared hopes for the future among their participants. This approach may yield more dissimilar narratives if participants were more homogeneous (with regard to socio-economic, cultural, and political background) within the groups creating the scenarios, while maximizing diversity between teams.

Finally, one of the most difficult aspects of this visioning exercise was to imagine how prevailing power structures and entrenched interests may be broken down. More time spent exploring potential pathways of change and important leverage points through the Three Horizons exercise may help tether the scenarios more closely to the present, and make them seem less implausible and fictional. Especially if the content of the scenarios is to be useful and informative to others beyond the participants of the workshop, it becomes necessary to provide reasonable roadmaps towards these positive visions. This may be an area ripe for methodological innovation. Recent developments in tools such as science fiction prototyping could help bridge the gap between possible and impossible (Author et al., 2018). In addition, knowledge from emerging fields such as Contemplative Studies could further improve existing methods like Verge, which prompt awareness and mindfulness of our relationship with one another, and with the environment. The enactive approaches to knowledge production and transdisciplinary thinking advocated by practitioners in this field may help nurture the reflective elements of visioning tools and cultivate new mindsets to re-define social and environmental challenges (Bentz \& Giorgino, 2016).

\section{CONCLUSIONS}

The Good Anthropocene visions present highly creative, alternative futures for southern Africa that are distinct from most other future narratives for the region. The visions highlight the need for more decentralized and equitable decision-making, a stronger voice for the citizenry, more empathetic relationships between people, and an enhanced appreciation and respect for nature. They also embrace an alternative, circular, and sharing-based economy, in a shift away from neo-liberal economic principles. The scenarios differ mainly in terms of the level of enmeshment between people and technology, as well as between people and nature. However, 
none of the above findings require a specifically African geography to be relevant. There are details within each storyline that speak to the southern African focus of the visions (such as the reference to the Ubuntu philosophy that guides decision-making in the Demos42 Ubuntunse scenario), but in general, the resulting narratives would make sense anywhere in the world. They therefore offer a southern African perspective on globally relevant stories of more desirable Anthropocene futures. Since the lack of diverse, and in particular African, perspectives has been referred to as "a continent-sized hole" in stories of the future (Author et al. in press), the visions presented here are an important contribution to the portfolio of optimistic stories for Africa, and elsewhere. How to start these transitions to positive futures, however, needs more exploration and diverse methodologies that nurture non-linear thinking and better incorporate the emotional dimensions of social change. It is hoped that similar visioning exercises, combined with experimental methodologies from emerging fields of knowledge, can be undertaken in other regions of the world that tend to be marginalized in conventional scenario processes, so that the rich bio-cultural diversity of the planet can be captured in pathways for navigating the Anthropocene onto a more desirable trajectory.

\section{ACKNOWLEDGEMENTS}

The authors wish to thank the other participants of the 2016 SOGA workshop in Cape Town: Deon Cloete, Lorenzo Fioramonti, Maxwell Gomera, Lauren Hermanus, Liza Johnson, Alexandra Karakashian, Zayaan Khan, Gys Loubser, Lelani Mannetti, Sithembile Mbete, Sekamotho Mirriam Moteane, Fumani Mthembi, Musonda Mumba, Phumlani Nkontwana, Rael Salley, Eduardo Shimahara, and Nelisiwe Xaba. Their dedication and enthusiasm throughout the visioning process was remarkable. Illustrations were created by Grant Johnson from Graphic Harvest. This paper has been produced as part of the Guidance for Resilience in the Anthropocene: Investments for Development (GRAID) Programme led by the Stockholm Resilience Centre at Stockholm University, and funded by the Swedish Development Cooperation Agency (Sida), as well as a South African Research Chairs Initiative (SARChI) grant held by Reinette Biggs and funded by the Department of Science and Technology and National Research Foundation of South Africa (grant 98766); and a Young Researchers Grant from the Vetenskapsrådet in Sweden (grant 621-2014-5137). Samuel Poskitt was supported by the UK Economic and Social Research Council and the James Hutton Institute. Ryan Blanchard was supported by SWEDBIO and the Council for Scientific and Industrial Research in South Africa.

\section{APPENDIX A}

The following table is a brief overview of the different "seed" initiatives that were chosen for the Good Anthropocene Visioning workshop. The participants were divided into four groups. Each group received descriptions of three seeds, which they used to build their scenario. The colour-coding indicates which seeds were selected to be in the same group. Seeds within a group were purposefully chosen to represent dissimilar and diverse initiatives, to allow innovative and radical connections to be made in the scenario development process. In the end, the following scenarios emerged from these groups: green $=$ Rhiz(h)ome; yellow $=$ Radical TransLocal; blue $=$ Post Exodus; red $=$ Demos42 Ubuntunse . 


\begin{tabular}{|c|c|c|}
\hline Seed initiative & Brief description & More info \\
\hline Tyisa Nabanye & $\begin{array}{l}\text { Tyisa Nabanye is a non-profit organization located on the slopes of } \\
\text { Signal Hill in Cape Town. Started in August 2013, this collaboration } \\
\text { between food security activists, neighbours and people living on the } \\
\text { site, aims to create a space in which to explore the growing of food in } \\
\text { an urban environment. Activities include an organic vegetable garden, } \\
\text { an indigenous nursery, a weekly market, workshops and events that } \\
\text { support the goals of food security and employment creation. }\end{array}$ & $\begin{array}{l}\text { https://www. } \\
\text { facebook.co } \\
\text { m/tyisanaba } \\
\text { nye/ }\end{array}$ \\
\hline Massive Small & $\begin{array}{l}\text { Massive small is a global network changing systems to unleash the } \\
\text { power of smallness in cities. It was established five years ago as an } \\
\text { independent, free thinking, open-source organization. } \\
\text { The massive small project is the work of the smart urbanism research } \\
\text { and development collaborative, a London based social value business. } \\
\text { They are creating a concise body of collective knowledge designed to } \\
\text { change top-down systems to help and inspire people and governments } \\
\text { to work together, allowing communities to shape their own } \\
\text { environments and make towns and cities that work for the people, not } \\
\text { against them. }\end{array}$ & $\begin{array}{l}\text { http://www. } \\
\text { massivesmall } \\
\text {.org }\end{array}$ \\
\hline Cryptocurrency & $\begin{array}{l}\text { Cryptocurrency is a digital or virtual currency that uses cryptography for } \\
\text { security. A cryptocurrency is difficult to counterfeit, and is not issued by } \\
\text { any central authority, rendering it theoretically immune to government } \\
\text { interference or manipulation. This digital currency makes it easier to } \\
\text { transfer funds with minimal processing fees, allowing users to avoid the } \\
\text { steep fees charged by most banks and financial institutions for wire } \\
\text { transfers. }\end{array}$ & $\begin{array}{l}\text { http://www.i } \\
\text { nvestopedia. } \\
\text { com/terms/c } \\
\text { /cryptocurre } \\
\text { ncy.asp }\end{array}$ \\
\hline $\begin{array}{l}\text { Community } \\
\text { Based Natural } \\
\text { Resource } \\
\text { Management }\end{array}$ & $\begin{array}{l}\text { CBNRM is a concept based on the ideas of community participation in } \\
\text { the management of natural resources through democratic } \\
\text { decentralization that leads to development and poverty alleviation, } \\
\text { whilst also resulting in the sustainable use and conservation of natural } \\
\text { resources. It empowers communities by providing rights over land and } \\
\text { natural resources, building skills capacity, establishing community } \\
\text { decision making bodies and promoting community advocacy. }\end{array}$ & $\begin{array}{l}\text { https://en.wi } \\
\text { kipedia.org/ } \\
\text { wiki/Natural_ } \\
\text { resource_ma } \\
\text { nagement\#C } \\
\text { ommunity- } \\
\text { based_natur } \\
\text { al_resource_- } \\
\text { management }\end{array}$ \\
\hline $\begin{array}{l}\text { Reconstructed } \\
\text { Living Lab } \\
\text { (RLabs) }\end{array}$ & $\begin{array}{l}\text { This global social enterprise was founded in } 2008 \text { and aims to } \\
\text { reconstruct communities through training, innovation and } \\
\text { entrepreneurship. The main hub is located in Athlone, Cape Town. RLabs } \\
\text { creates an environment where people are empowered to make a } \\
\text { difference in the lives of others. Its central activities are skills and } \\
\text { training, community development, social and disruptive innovation, } \\
\text { mobile and internet solutions, social enterprise incubation, impact } \\
\text { investing and social franchising. }\end{array}$ & $\begin{array}{l}\text { http://rlabs.o } \\
\text { rg/ }\end{array}$ \\
\hline
\end{tabular}




\begin{tabular}{|c|c|c|}
\hline Artificial Meat & $\begin{array}{l}\text { Artificial meat (in-vitro meat) is the idea of manufacturing meat } \\
\text { products through tissue engineering technology, using many of the } \\
\text { same techniques traditionally used in regenerative medicine. The first } \\
\text { cultured beef burger patty was created in } 2013 \text {. The creation process of } \\
\text { cultured meat includes harvesting muscle stem cells from cow neck by } \\
\text { means of biopsy. These cells are then induced to grow into muscle tissue } \\
\text { in a lab. In a life cycle analysis, it was calculated that in vitro meat may } \\
\text { significantly reduce the environmental footprint of meat consumption. }\end{array}$ & $\begin{array}{l}\text { https://en.wi } \\
\text { kipedia.org/ } \\
\text { wiki/Cultured } \\
\text { _meat }\end{array}$ \\
\hline $\begin{array}{l}\text { Open Streets } \\
\text { Cape Town }\end{array}$ & $\begin{array}{l}\text { OSCT is a citizen-driven initiative working towards changing how streets } \\
\text { are used, perceived and experienced in Cape Town. Rooted in "street } \\
\text { action" and research, the aim is to create shared spaces that bring } \\
\text { people together, and to challenge the paradigm of urban mobility by } \\
\text { carrying out campaigns, temporary interventions, dialogues and walks } \\
\text { that raise citizen awareness, spark public debate, and ultimately drive } \\
\text { behaviour change around the role of streets in the life of the city. }\end{array}$ & $\begin{array}{l}\text { http://openst } \\
\text { reets.org.za/ }\end{array}$ \\
\hline Knowledge Pele & $\begin{array}{l}\text { Knowledge Pele is a research and development advisory firm who } \\
\text { believes in knowledge as the foundation for development. The } \\
\text { institution's main goal is to be the leading source of granular information } \\
\text { about under-privileged communities, to guide the design of innovative } \\
\text { and impactful social investments. The purpose of the company is to } \\
\text { develop energy communities, by catalysing structural change through } \\
\text { businesses that generate power and knowledge. }\end{array}$ & $\begin{array}{l}\text { http://www. } \\
\text { knowledgepe } \\
\text { le.com/index } \\
\text {.html }\end{array}$ \\
\hline $\begin{array}{l}\text { Gene Editing } \\
\text { Technologies }\end{array}$ & $\begin{array}{l}\text { Gene editing allows changing the DNA of any organism. More precisely, } \\
\text { gene editing (or genome editing) is the insertion, deletion or } \\
\text { replacement of DNA at a specific site in the genome of an organism or } \\
\text { cell. It is achieved using engineered nucleases, also known as molecular } \\
\text { scissors. Until recently, this editing process was incredibly time } \\
\text { consuming and cumbersome. In contrast, CRISPR- Cas } 9 \text {, a new gene } \\
\text { editing technology that emerged in the last }+/-5 \text { years, is cheap, quick } \\
\text { and easy to use. Given the power and potential of this new technique, } \\
\text { researchers hope to use it to eliminate diseases, for example, or create } \\
\text { hardier crops. While it is clear that CRISPR has much to offer, its rapid } \\
\text { acceleration of the gene editing field has also caused concern about the } \\
\text { ethics and safety of its use. }\end{array}$ & $\begin{array}{l}\text { http://www. } \\
\text { nature.com/ } \\
\text { news/crispr- } \\
1.17547\end{array}$ \\
\hline $\begin{array}{l}\text { Future Cape } \\
\text { Town }\end{array}$ & $\begin{array}{l}\text { Future Cape Town was founded in } 2010 \text { and has become a leading } \\
\text { platform in Africa to inspire more liveable cities. Through their online } \\
\text { presence, research and multi-stakeholder collaborations they work } \\
\text { towards expanding public access to urbanism in order to promote a } \\
\text { more visionary and inclusive city. They are an independent think tank, } \\
\text { advocating knowledge and citizen engagement to meet the challenges } \\
\text { of a modern city. Future Cape Town is the founding partner of Our } \\
\text { Future Cities, which also houses Future Johannesburg, Future Lagos and } \\
\text { Future London. }\end{array}$ & $\begin{array}{l}\text { http://future } \\
\text { capetown.co } \\
\text { m/ }\end{array}$ \\
\hline $\begin{array}{l}\text { Slow Food Youth } \\
\text { Network }\end{array}$ & $\begin{array}{l}\text { SFYN is an international network of young people working towards } \\
\text { change in the field of food production and consumption. The network } \\
\text { believes in the philosophy of "good, clean and fair" food as a reaction } \\
\text { against the upcoming fast food chains. The network unites groups of } \\
\text { active young Slow Food members over the globe into one international }\end{array}$ & $\begin{array}{l}\text { http://www.s } \\
\text { lowfoodyout } \\
\text { hnetwork.org } \\
\text { / }\end{array}$ \\
\hline
\end{tabular}




\begin{tabular}{|l|l|l|}
\hline & $\begin{array}{l}\text { network, raising awareness about food issues and providing means to } \\
\text { take action. }\end{array}$ & \\
\hline $\begin{array}{l}\text { Artificial } \\
\text { Intelligence }\end{array}$ & $\begin{array}{l}\text { Artificial Intelligence (AI) is the science of making computers perform } \\
\text { tasks that require human intelligence. The goal of Al is to build systems } \\
\text { that can match or exceed the cognitive capabilities of human beings } \\
\text { across a range of domains. This holds potential to drive incredible } \\
\text { efficiencies, increase productivity, and if Al reaches its potential, it will } \\
\text { likely change our world in unexpected ways. Al has slowly become a } \\
\text { major part of our world without some of us even noticing. Indeed, one } \\
\text { of the most sophisticated pieces of specialised Al in use today is the } \\
\text { Google Search Algorithm. }\end{array}$ & $\begin{array}{l}\text { al } \\
\text { antigence- } \\
\text { revolution- } \\
1 . h t m l\end{array}$ \\
\hline
\end{tabular}




\section{REFERENCES}

Adger, W. N., Barnett, J., Brown, K., Marshall, N., \& O'Brien, K. (2013). Cultural dimensions of climate change impacts and adaptation. Nature Climate Change Change, 3(2), 112-117. https://doi.org/http://dx.doi.org/10.1038/nclimate1666

African Union Commission. (2015). Agenda 2063: The Africa We Want. Addis Ababa, Ethiopia.

Bennett, E. M., Solan, M., Biggs, R., McPhearson, T., Norström, A. V, Olsson, P., ... Xu, J. (2016). Bright spots: Seeds of a good Anthropocene. Frontiers in Ecology and the Environment, 14(8), 441-448. https://doi.org/10.1002/fee.1309

Bentz, V. M., \& Giorgino, V. M. . (2016). Contemplative social research: Caring for self, being, and lifeworld. Santa Barbara, CA, USA: Fielding University Press.

Bishop, P., Hines, A., \& Collins, T. (2007). The current state of scenario development: An overview of techniques. Foresight, 9(1), 5-25. https://doi.org/10.1108/14636680710727516

Clammer, J. (2014). Art and the arts of sustainability. Social Alternatives, 33(3), 65-70.

Cooperrider, D. L. (2001). Positive image, positive action: The affirmative basis of organizing. In D. L. Cooperrider, P. F. Sorensen Jr, T. F. Yaeger, \& D. Whitney (Eds.), Appreciative inquiry: an emerging direction for organization development (pp. 31-76). Champaign, IL, USA: Stipes Publishing L.L.C.

Cork, S., Peterson, G., Petschel-Held, G., Alcamo, J., Alder, J., Bennett, E., .. Zurek, M. (2005). Four scenarios. In S. R. Carpenter, P. L. Pingali, E. M. Bennett, \& M. Zurek (Eds.), Ecosystems and human well-being: Scenarios, volume 2. Findings of the Scenarios Working Group, Millennium Ecosystem Assessment. Washington, DC, USA: Island Press.

Costanza, R. (2000). Visions of alternative (unpredictable) futures and their use in policy analysis. Conservation Ecology, 4(1), 5. https://doi.org/http://www.consecol.org/vol4/iss1/art5/

Crutzen, P. J. (2002). Geology of mankind. Nature, 415(6867), 23. https://doi.org/10.1038/415023a

CST-GRAID. (2017). Report on the Anthropocene Visioning Workshop, 15-18 November 2016, Cape Town, South Africa. GRAID project workshop. Stellenbosch, South Africa.

CST. (2017). Seeds of Good Anthropocenes. Retrieved September 20, 2017, from http://www0.sun.ac.za/cst/major-project/seeds-of-good-anthropocenes/

Curry, A., \& Hodgson, A. (2008). Seeing in multiple horizons: Connecting futures to strategy. Journal of Futures Studies, 13(1), 1-20.

Curry, A., \& Schultz, W. (2009). Roads less travelled: Different methods, different futures. Journal of Futures Studies, 13(4), 35-60.

Diffenbaugh, N. S., \& Burke, M. (2019). Global warming has increased global economic inequality. Proceedings of the National Academy of Sciences. https://doi.org/10.1073/pnas.1816020116

Falardeau, M., Raudsepp-Hearne, C., \& Bennett, E. M. (2018). A novel approach for co-producing positive scenarios that explore agency: Case study from the Canadian Arctic. Sustainability Science. https://doi.org/10.1007/s11625-018-0620-z

Folke, C., Jansson, Å., Rockström, J., Olsson, P., Carpenter, S. R., Stuart Chapin, F., ... Westley, F. (2011). Reconnecting to the biosphere. Ambio, 40(7), 719-738. https://doi.org/10.1007/s13280011-0184-y

Fredrickson, B. L. (2001). The role of positive emotions in positive psychology. The broaden-and-build theory of positive emotions. The American Psychologist, 56(3), 218-226. https://doi.org/http://dx.doi.org/10.1037/0003-066X.56.3.218 
Gallopin, G., Hammond, A., Raskin, P., \& Swart, R. (1997). Branch points: Global scenarios and human choice (PoleStar Series Report no. 7). Stockholm, Sweden.

Geels, F. W., Sovacool, B. K., Schwanen, T., \& Sorrell, S. (2017). Sociotechnical transitions for deep decarbonization. Science, 357(6357), 1242-1244. https://doi.org/10.1126/science.aao3760

Gibson-Graham, J. K. (2006). The end of capitalism (as we knew it): A feminist critique of political economy. Minneapolis, MN, USA: University of Minnesota Press.

Gilbert, D. T., \& Wilson, T. D. (2007). Prospection: Experiencing the future. Science, 317(5843), 1351 LP-1354. https://doi.org/10.1126/science.1144161

Glenn, J. C. (2009). The Futures Wheel. In J. C. Glenn \& T. J. Gordon (Eds.), Futures Research Methodology. Washington, DC, USA: Millennium Project.

Hull, V., \& Liu, J. (2018). Telecoupling: A new frontier for global sustainability. Ecology and Society, 23(4), 41. https://doi.org/10.5751/ES-10494-230441

Hunt, D. V. L., Lombardi, D. R., Atkinson, S., Barber, A. R. G., Barnes, M., Boyko, C. T., ... Rogers, C. D. F. (2012). Scenario archetypes: Converging rather than diverging themes. Sustainability, 4(4), 740-772. https://doi.org/10.3390/su4040740

IPCC. (2000). Emissions scenarios. (N. Nakicenovic \& R. Swart, Eds.). Cambridge, UK: Cambridge University Press.

Korotayev, A., Zinkina, J., \& Bogevolnov, J. (2011). Kondratieff waves in global invention activity (1900-2008). Technological Forecasting and Social Change, 78(7), 1280-1284. https://doi.org/https://doi.org/10.1016/j.techfore.2011.02.011

Kretzmann, J. P., \& McKnight, J. L. (1993). Building communities from the inside out: a path toward finding and mobilizing a community's assets. Chicago, IL, USA: ACTA Publications.

Kurzweil, R. (2005). The singularity is near: When humans transcend biology. New York, NY, USA: Penguin Books.

Liberman, N., Sagristano, M. D., \& Trope, Y. (2002). The effect of temporal distance on level of mental construal. Journal of Experimental Social Psychology, 38(6), 523-534. https://doi.org/http://dx.doi.org/10.1016/S0022-1031(02)00535-8

Linstone, H. A., \& Devezas, T. (2012). Technological innovation and the long wave theory revisited. Technological Forecasting and Social Change, 79(2), 414-416. https://doi.org/https://doi.org/10.1016/j.techfore.2011.11.001

Loewenstein, G., O'Donoghue, T., \& Rabin, M. (2003). Projection bias in predicting future utility. The Quarterly Journal of Economics, 118(4), 1209-1248. https://doi.org/10.1162/003355303322552784

Lum, R. A. K. (2015). Working with Verge. APF Compass. Methods Anthology., 5-8.

Lundquist, C. J., Pereira, H. M., Alkemade, J. R. M., den Belder, E., Carvalho Ribeiro, S., Davies, K., ... Lindgren-Streicher, P. (2017). Visions for nature and nature's contributions to people for the 21 st century. (NIWA Science and Technology Series No. 83). Auckland, New Zealand. Retrieved from https://www.niwa.co.nz/naturefutures

McRae, L., Deinet, S., \& Freeman, R. (2017). The diversity-weighted Living Planet Index: Controlling for taxonomic bias in a global biodiversity indicator. PLOS ONE, 12(1), e0169156. https://doi.org/https://doi.org/10.1371/journal.pone.0169156

Morton, T. A., Rabinovich, A., Marshall, D., \& Bretschneider, P. (2011). The future that may (or may not) come: How framing changes responses to uncertainty in climate change communications. Global Environmental Change, 21(1), 103-109. https://doi.org/10.1016/j.gloenvcha.2010.09.013

Mulgan, G. (2006). The process of social innovation. Innovations: Technology, Governance, Globalization, 1(2), 145-162. https://doi.org/https://doi.org/10.1162/itgg.2006.1.2.145

Nefiodow, L., \& Nefiodow, S. (2014). The sixth Kondratieff: The new long wave in the global economy. Sankt Augustin, Germany: Leo Nefiodow.

O'Brien, K. L., \& Leichenko, R. M. (2000). Double exposure: Assessing the impacts of climate change within the context of economic globalization. Global Environmental Change, 10(3), 221-232. https://doi.org/http://doi.org/10.1016/S0959-3780(00)00021-2

O’Neill, S., \& Nicholson-Cole, S. (2009). "Fear won't do it": Promoting positive engagement with climate change through visual and iconic representations. Science Communication, 30(3), 355379. https://doi.org/10.1177/1075547008329201 
Oteros-Rozas, E., Martin-Lopez, B., Daw, T. M., Bohensky, E. L., Butler, J. R. A., Hill, R., ... Vilardy, S. P. (2015). Participatory scenario planning in place-based social-ecological research: Insights and experiences from 23 case studies. Ecology and Society, 20(4). https://doi.org/10.5751/ES07985-200432

Pang, A. S. K. (2010). Futures 2.0: Rethinking the discipline. Foresight, 12(1), 5-20. https://doi.org/10.1108/14636681011020191

Pearce, F. (2013). New green vision: Technology as our planet's last best hope. Yale Environment 360. Retrieved

from http://e360.yale.edu/features/new_green_vision_technology_as_our_planets_last_best_hope

Peterson, C. M., \& Seligman, M. E. P. (2003). Positive organizational studies: Lessons from positive psychology. In K. S. Cameron, J. E. Dutton, \& R. E. Quinn (Eds.), Positive organizational scholarship: Foundations of a new discipline. San Francisco, CA, USA: Berret-Koehler Publishers Inc.

Peterson, G. D., Cumming, G. S., \& Carpenter, S. R. (2003). Scenario planning: A tool for conservation in an uncertain world. Conserv. Biol., 17(2), 358-366. https://doi.org/10.1046/j.15231739.2003.01491.x

Piketty, T., \& Saez, E. (2014). Inequality in the long run. Science, 344(6186), 838-843. https://doi.org/10.1126/science.1251936

Polak, F. (1973). The image of the future. Amsterdam, The Netherlands: Elsevier Scientific Publishing Company.

Raskin, P., Banuri, T., Gallopin, G., Gutman, P., Hammond, A., Kates, R., \& Swart, R. (2002). Great Transition: the promise and lure of the times ahead. A report of the Global Scenario Group. Boston, USA.

Schultz, W. (2015). Mānoa: The future is not binary. APF Compass. Methods Anthology., 22-26.

Seligman, M. E. P., \& Csikszentmihalyi, M. (2000). Positive psychology: An introduction. American Psychologist. US: American Psychological Association. https://doi.org/10.1037/0003066X.55.1.5

Sharpe, B. (2015). Three Horizons and working with change. APF Compass. Methods Anthology., 911.

Steffen, W., Broadgate, W., Deutsch, L., Gaffney, O., \& Ludwig, C. (2015). The trajectory of the Anthropocene: The great acceleration. The Anthropocene Review, 2(1), 81-98. https://doi.org/10.1177/2053019614564785

Steffen, W., Persson, A., Deutsch, L., Zalasiewicz, J., Williams, M., Richardson, K., ... Svedin, U. (2011). The anthropocene: From global change to planetary stewardship. Ambio, 40(7), 739-761. https://doi.org/10.1007/s13280-011-0185-x

Steffen, W., Richardson, K., Rockström, J., Cornell, S., Fetzer, I., Bennett, E., .. Carpenter, S. (2015). Planetary boundaries: Guiding human development on a changing planet. Science, 347(6223), 1259855. https://doi.org/10.1126/science.aaa9629

Steffen, W., Rockström, J., Richardson, K., Lenton, T. M., Folke, C., Liverman, D., ... Schellnhuber, H. J. (2018). Trajectories of the Earth system in the Anthropocene. Proceedings of the National Academy of Sciences, 115(33), 8252-8259. https://doi.org/10.1073/pnas.1810141115

UNEP. (2016). GEO-6 Regional Assessment for Africa. Nairobi, Kenya.

Unger, R. M. (2015). Conclusion: The task of the social innovation movement. In A. Nicholls, J. Simon, M. Gabriel, \& C. Whelan (Eds.), New frontiers in social innovation research (pp. 23-251). London, UK: Palgrave Macmillan.

van Vuuren, D. P., Kok, M. T. J., Girod, B., Lucas, P. L., \& de Vries, B. (2012). Scenarios in global environmental assessments: Key characteristics and lessons for future use. Global Environmental Change, 22(4), 884-895. https://doi.org/https://doi.org/10.1016/j.gloenvcha.2012.06.001

Vervoort, J., Palazzo, A., Mason-D’Croz, D., Ericksen, P., Thornton, P., Kristjanson, P., ... Rowlands, H. (2013). The future of food security, environments and livelihoods in Eastern Africa: four socioeconomic scenarios. CCFAS Working Paper No. 63. Copenhagen, Denmark.

Yusoff, K., \& Gabrys, J. (2011). Climate change and the imagination. Wiley Interdisciplinary Reviews: Climate Change, 2(4), 516-534. https://doi.org/10.1002/wcc.117 


\section{FIGURE CAPTIONS}

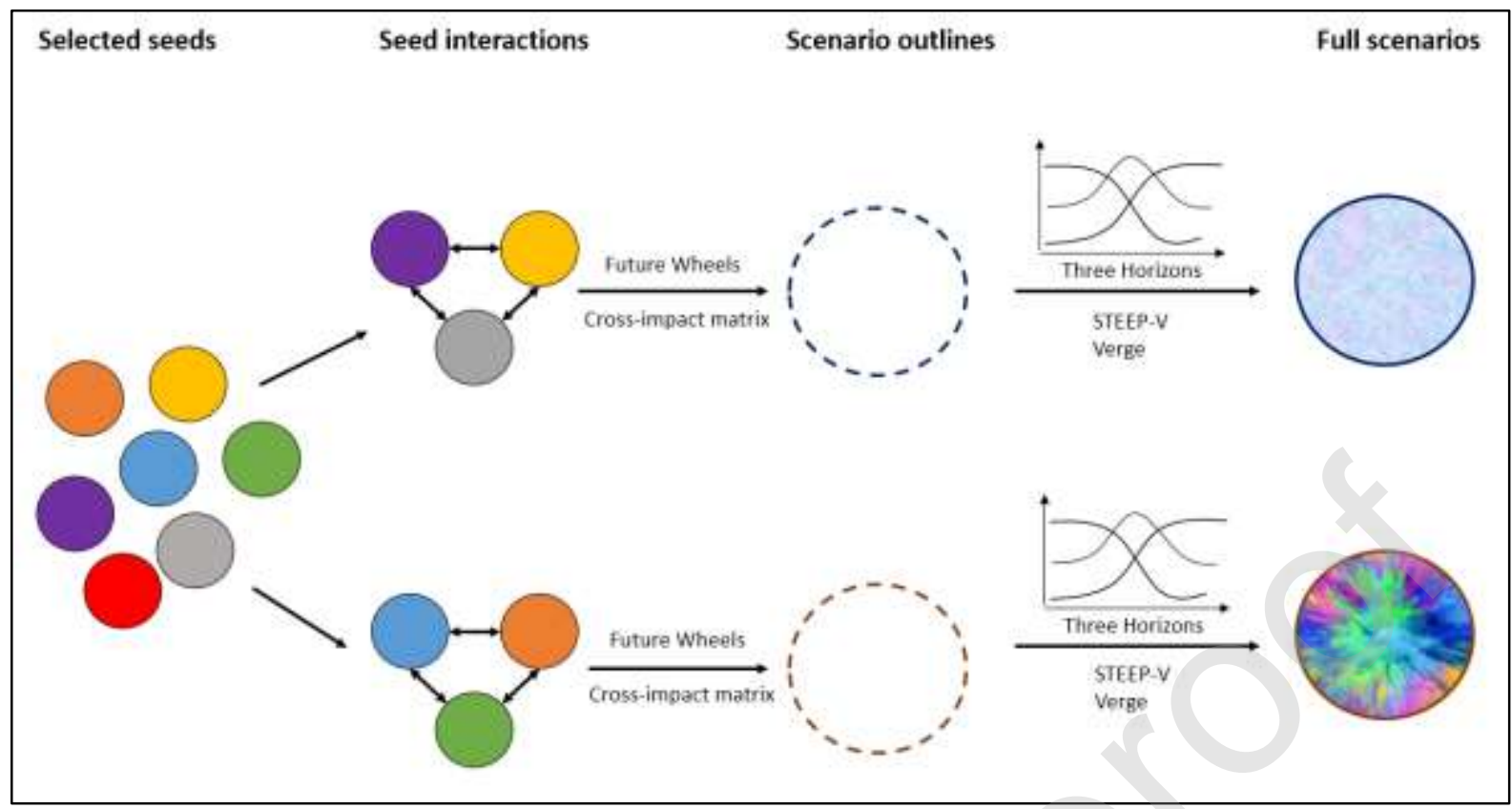

Fig.1 Summary of the SOGA visioning process. Scenarios are built up from a set of seeds and their interactions, with narrative details and potential pathways connecting the future to the present added in subsequent steps.

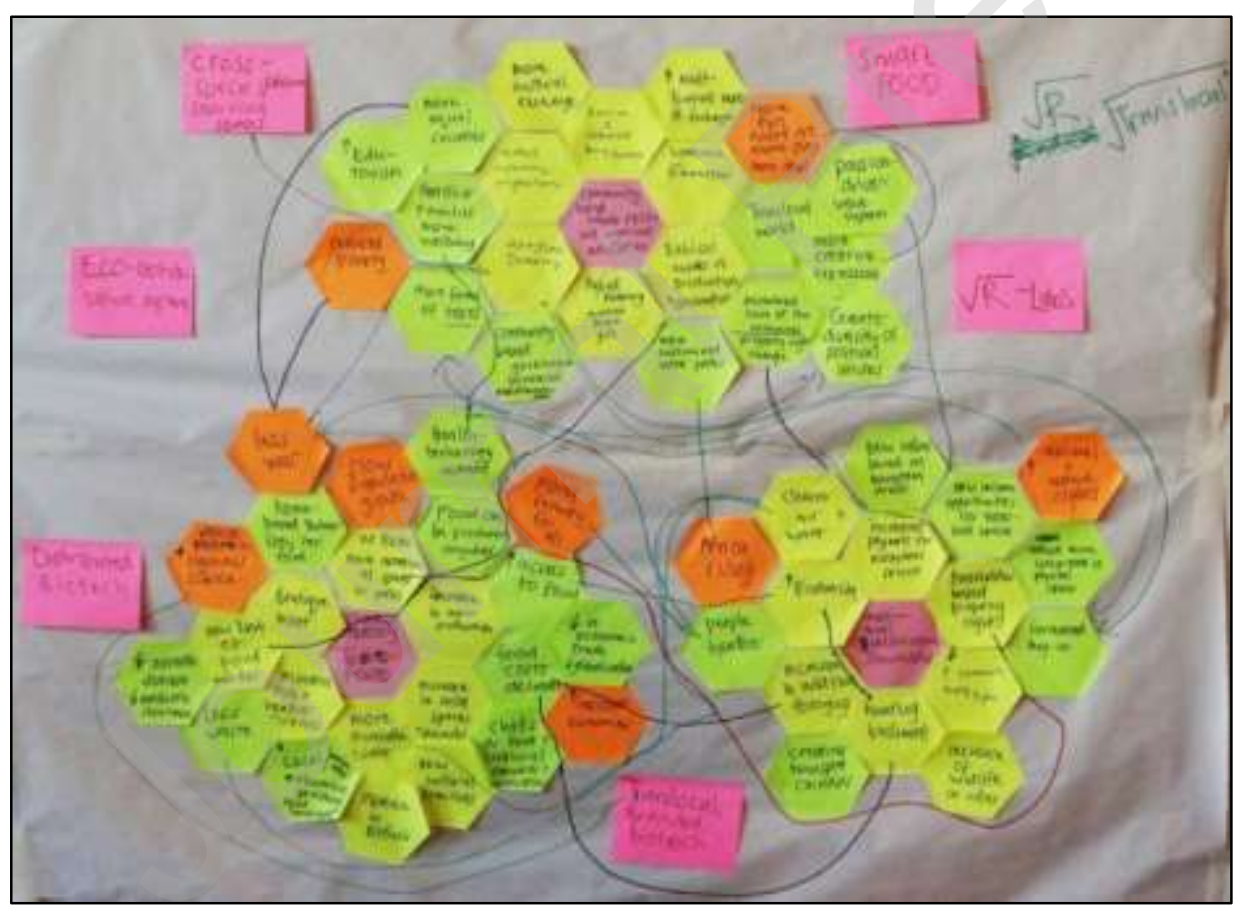

Fig. 2 Example of a set of three Futures Wheels and their interactions 


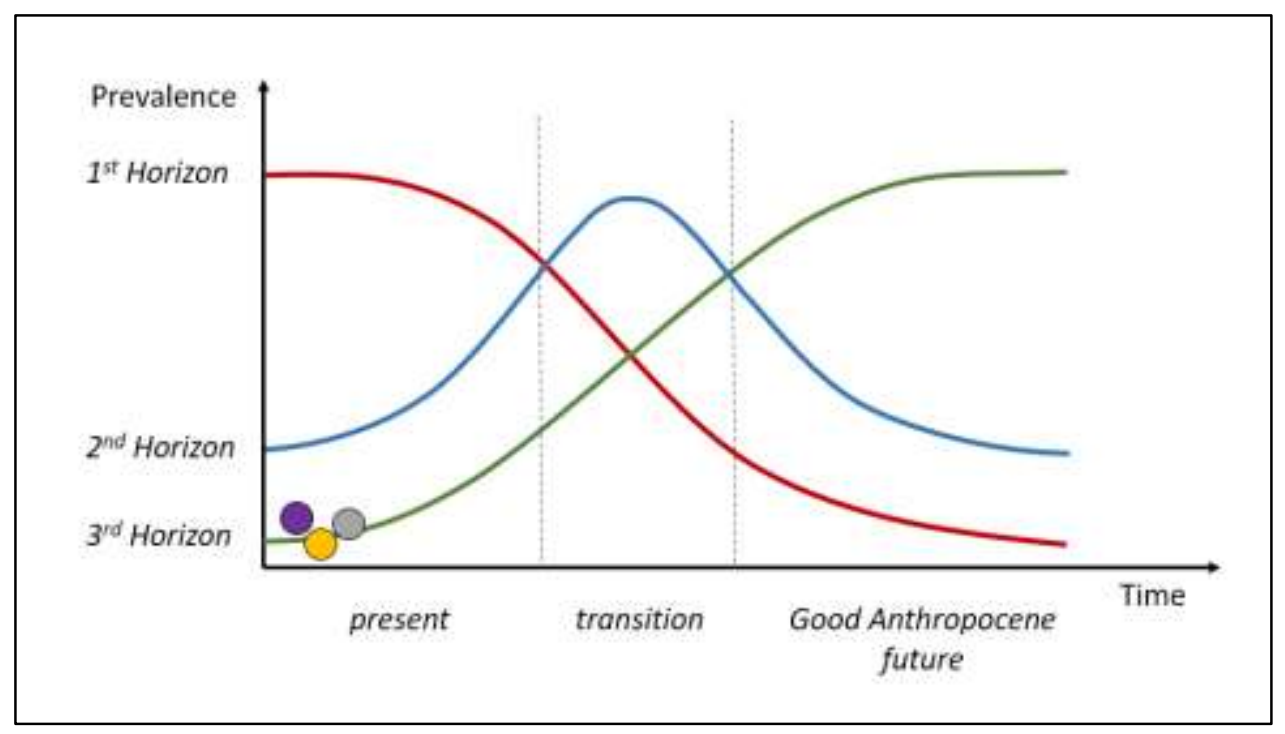

Fig. 3 The Three Horizons framework, depicted with seeds in the early stages of the $3^{\text {rd }}$ Horizon to represent the emerging ideas that grow in the present to become part of a positive future. Figure adapted from Sharpe (2015).

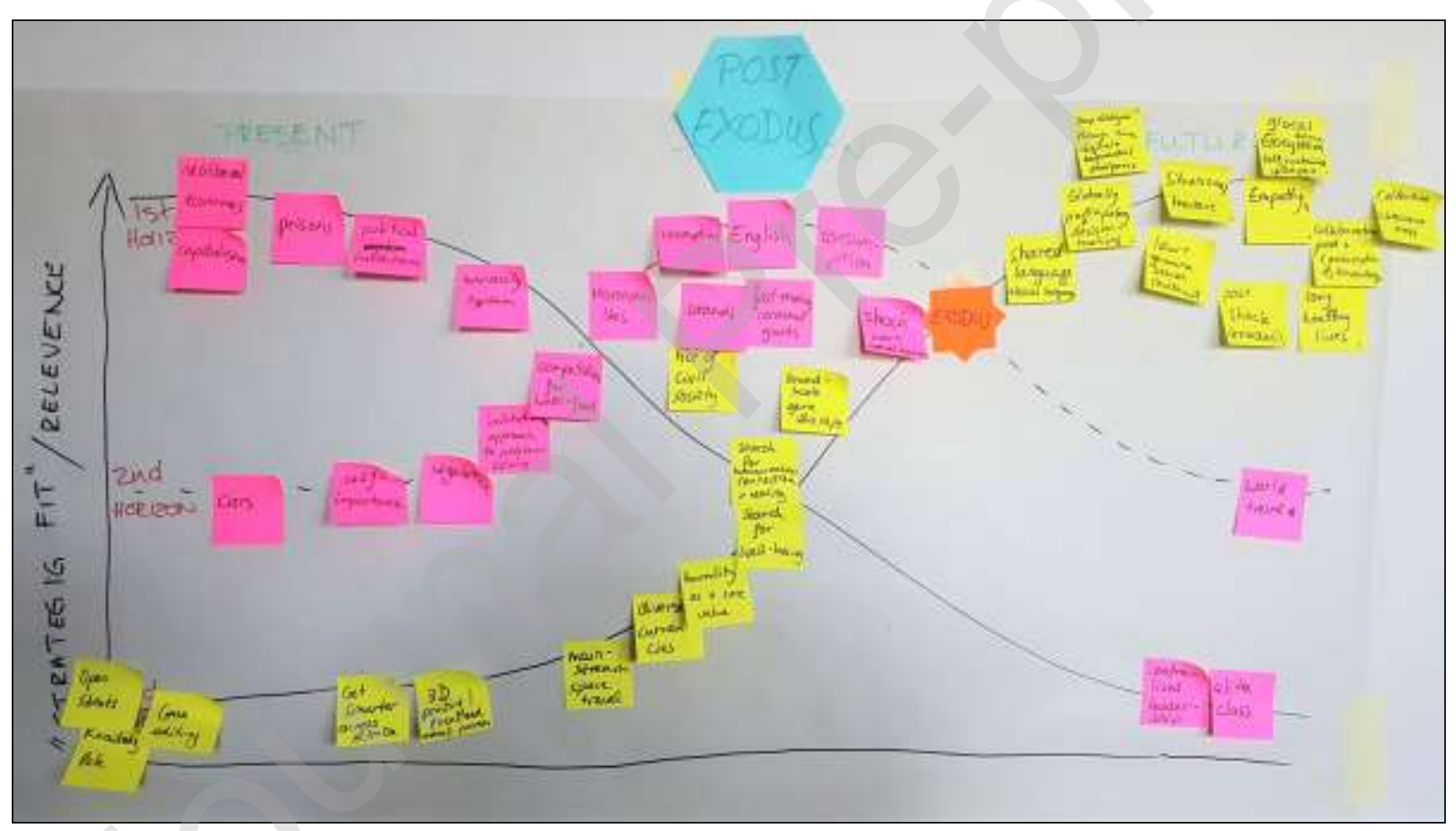

Fig. 4 Example of the Three Horizons exercise used to identify turning points and pathways towards positive futures 
Table 1. Summary table outlining the similarities between the scenarios

\begin{tabular}{|c|c|c|c|c|}
\hline Themes & Rhiz(h)ome & Post Exodus & \begin{tabular}{|l|} 
Demos42 \\
Ubuntunse
\end{tabular} & Radical TransLocal \\
\hline $\begin{array}{l}\text { Decentralised } \\
\text { Governance }\end{array}$ & $\begin{array}{l}\text { Local, citizen-led } \\
\text { governance, built on } \\
\text { traditional structures. } \\
\text { Connected to higher- } \\
\text { level governance that } \\
\text { help redistribute } \\
\text { resources, manage } \\
\text { regional common } \\
\text { goods, mediate } \\
\text { conflicts, and help in } \\
\text { disaster situations. }\end{array}$ & $\begin{array}{l}\text { Decisions are made } \\
\text { through a system of } \\
\text { deep dialogues, } \\
\text { which are held on } \\
\text { digital and physical } \\
\text { platforms (see below) } \\
\text { to enable a fully } \\
\text { participatory process. }\end{array}$ & $\begin{array}{l}\text { AI } \\
\text { superintelligence } \\
\text { allows for } \\
\text { collective decision- } \\
\text { making as needed. }\end{array}$ & $\begin{array}{l}\text { There are no nation } \\
\text { states and communities } \\
\text { are organized } \\
\text { locally/regionally. A } \\
\text { direct democracy } \\
\text { allows for daily voting } \\
\text { through electronic } \\
\text { devices where citizens } \\
\text { can cast votes on what } \\
\text { needs to be } \\
\text { done/decided. }\end{array}$ \\
\hline Connectedness & $\begin{array}{l}\text { People belong to } \\
\text { multiple communities } \\
\text { linked through the } \\
\text { internet, and } \\
\text { communication is } \\
\text { enhanced through } \\
\text { universal translation. } \\
\text { Collaboration and } \\
\text { partnership inform the } \\
\text { underlying societal } \\
\text { norms. Growth of } \\
\text { cooperatives and other } \\
\text { citizen-based } \\
\text { coalitions. }\end{array}$ & $\begin{array}{l}\text { People come together } \\
\text { in "The Collective", a } \\
\text { physical and virtual } \\
\text { community space that } \\
\text { is both highly local } \\
\text { and global. Central to } \\
\text { The Collective is the } \\
\text { building of } \\
\text { understanding } \\
\text { between people, } \\
\text { cultures and contexts, } \\
\text { to encourage empathy } \\
\text { and humility. }\end{array}$ & $\begin{array}{l}\text { Demos } 42 \text {, connects } \\
\text { and guides } \\
\text { humanity in the } \\
\text { spirit of Ubuntu. } \\
\text { People are } \\
\text { completely open to } \\
\text { Demos } 42 \text { and all } \\
\text { factual information } \\
\text { is available to } \\
\text { everyone through } \\
\text { the AI. However, } \\
\text { people are able to } \\
\text { keep their emotions } \\
\text { and feelings private } \\
\text { if they wish. }\end{array}$ & $\begin{array}{l}\text { E-trains that run in } \\
\text { underground tunnels } \\
\text { connect people in cities } \\
\text { to local villages that } \\
\text { are in close proximity } \\
\text { to the urban areas. } \\
\text { Indigenous knowledge } \\
\text { systems have been re- } \\
\text { discovered as a source } \\
\text { of connectedness to } \\
\text { nature and each other. }\end{array}$ \\
\hline $\begin{array}{l}\text { Sharing } \\
\text { Economy }\end{array}$ & $\begin{array}{l}\text { Economy is driven by } \\
\text { services rather than } \\
\text { production, and } \\
\text { businesses specialize in } \\
\text { creating opportunities } \\
\text { for human fulfilment } \\
\text { and the generation and } \\
\text { sharing of knowledge, } \\
\text { e.g., instead of } \\
\text { producing goods, } \\
\text { businesses facilitate the } \\
\text { spread 3D printing } \\
\text { codes that citizens may } \\
\text { use to produce their } \\
\text { own goods. There is a } \\
\text { shift from private } \\
\text { ownership to common } \\
\text { goods. }\end{array}$ & $\begin{array}{l}\text { Communities shift to } \\
\text { highly localized, } \\
\text { direct production } \\
\text { systems using } \\
\text { technologies like 3D- } \\
\text { printing and } \\
\text { diversified currency } \\
\text { systems. As a result, } \\
\text { global monopolies } \\
\text { crumble and the } \\
\text { appeal of brands } \\
\text { diminishes. }\end{array}$ & $\begin{array}{l}\text { All knowledge and } \\
\text { information is } \\
\text { freely shared and } \\
\text { accessible. } \\
\text { Gastro-gardens in } \\
\text { cities are ubiquitous } \\
\text { and are free for all } \\
\text { to access food. }\end{array}$ & $\begin{array}{l}\text { The economy is a } \\
\text { hybrid between } \\
\text { different forms of } \\
\text { alternative currencies } \\
\text { such as a sharing and } \\
\text { gift economy, mixed } \\
\text { with VERITAS, a } \\
\text { virtual artificial } \\
\text { intelligence currency. }\end{array}$ \\
\hline $\begin{array}{l}\text { Emphasis on } \\
\text { human } \\
\text { fulfilment } \\
\text { rather than } \\
\text { work }\end{array}$ & $\begin{array}{l}\text { The notion of labour } \\
\text { has been replaced by } \\
\text { an emphasis on societal } \\
\text { contribution and } \\
\text { opportunities for self- } \\
\text { fulfilment, expression } \\
\text { and agency. More } \\
\text { meaningful use of time } \\
\text { e.g., less wastage of } \\
\text { time travelling/ }\end{array}$ & $\begin{array}{l}\text { Cultural and artistic } \\
\text { self-expression is } \\
\text { highly valued, } \\
\text { especially in The } \\
\text { Collective, where the } \\
\text { goal is to build shared } \\
\text { knowledge and a } \\
\text { collective } \\
\text { consciousness. } \\
\text { Everyone contributes }\end{array}$ & $\begin{array}{l}\text { Work is no longer } \\
\text { drudgery as there } \\
\text { are robots } \\
\text { coordinated and } \\
\text { deployed by the } \\
\text { artificial } \\
\text { superintelligence to } \\
\text { undertake mundane } \\
\text { tasks. }\end{array}$ & $\begin{array}{l}\text { People can choose } \\
\text { what to study or what } \\
\text { work they do based on } \\
\text { their interest and } \\
\text { aptitude, no work is } \\
\text { more important than } \\
\text { another, the skills are } \\
\text { exchanged in a sharing } \\
\text { economy. }\end{array}$ \\
\hline
\end{tabular}




\begin{tabular}{|c|c|c|c|c|}
\hline & $\begin{array}{l}\text { commuting and doing } \\
\text { mundane work. }\end{array}$ & $\begin{array}{l}\text { to their local } \\
\text { production systems. }\end{array}$ & & \\
\hline $\begin{array}{l}\text { Reduced } \\
\text { inequalities }\end{array}$ & $\begin{array}{l}\text { Reducing separation } \\
\text { between races, genders, } \\
\text { languages and cultures. } \\
\text { Difference is valued } \\
\text { and respected, and } \\
\text { there is formal recourse } \\
\text { for marginalized } \\
\text { groups. }\end{array}$ & $\begin{array}{l}\text { Leaders are } \\
\text { situational, not } \\
\text { permanent. Decisions } \\
\text { are made in highly } \\
\text { participatory ways by } \\
\text { consensus, and there } \\
\text { is complete sharing } \\
\text { of knowledge. The } \\
\text { accumulation of } \\
\text { material things is } \\
\text { unimportant, since } \\
\text { everything feeds back } \\
\text { into the cycle of use } \\
\text { and re-use. This leads } \\
\text { to a breakdown of } \\
\text { socio-economic, } \\
\text { political, and gender } \\
\text { inequalities. }\end{array}$ & $\begin{array}{l}\text { Gender is a fluid } \\
\text { concept, informed } \\
\text { by Demos } 42 \text { that } \\
\text { emerged from a } \\
\text { region where the } \\
\text { local Bantu } \\
\text { languages do not } \\
\text { differentiate } \\
\text { between male and } \\
\text { female speakers. As } \\
\text { Demos } 42 \text { is (S)he, } \\
\text { so the boundary } \\
\text { between men and } \\
\text { women and their } \\
\text { societal roles is } \\
\text { eroded. }\end{array}$ & $\begin{array}{l}\text { Children have voting } \\
\text { rights from 5yrs old } \\
\text { and learn to become } \\
\text { active citizens from a } \\
\text { young age. Society is } \\
\text { very equal and poverty } \\
\text { is minimal - this is } \\
\text { done through food } \\
\text { production that has } \\
\text { solved the problem of } \\
\text { food security. }\end{array}$ \\
\hline $\begin{array}{l}\text { Connection to } \\
\text { Nature }\end{array}$ & $\begin{array}{l}\text { Less distinction } \\
\text { between rural and } \\
\text { urban (urban design is } \\
\text { context-specific and in } \\
\text { tune with local } \\
\text { environment). There is } \\
\text { more awareness, } \\
\text { understanding, and } \\
\text { respect for nature, as } \\
\text { well as community- } \\
\text { based management of } \\
\text { natural resources \& } \\
\text { environments. }\end{array}$ & $\begin{array}{l}\text { Communities are } \\
\text { enterprising village } \\
\text { ecosystems, in tune } \\
\text { with their } \\
\text { environments and } \\
\text { focused on closed- } \\
\text { loop, no-waste } \\
\text { production systems. } \\
\text { Deep empathy } \\
\text { extends to the natural } \\
\text { world. }\end{array}$ & $\begin{array}{l}\text { Natural spaces that } \\
\text { do not shift like the } \\
\text { infrastructure are } \\
\text { sacrosanct, and } \\
\text { outside of the cities, } \\
\text { the non-human } \\
\text { world abounds. }\end{array}$ & $\begin{array}{l}\text { Eco-centric values } \\
\text { shape all the decisions } \\
\text { that people make. } \\
\text { Humans are closely } \\
\text { connected to nature } \\
\text { through indigenous } \\
\text { knowledge systems, } \\
\text { and there are no } \\
\text { "nature reserves". } \\
\text { Natural resources and a } \\
\text { connection to nature } \\
\text { are seen as the most } \\
\text { important values. The } \\
\text { arts play a crucial role } \\
\text { in regulating the } \\
\text { connectedness to } \\
\text { nature. }\end{array}$ \\
\hline Empathy & $\begin{array}{l}\text { The collective fear that } \\
\text { characterised previous } \\
\text { eras is replaced by a } \\
\text { focus on empathy. } \\
\text { People belong to } \\
\text { multiple communities } \\
\text { and there is an } \\
\text { emphasis on societal } \\
\text { contributions. }\end{array}$ & $\begin{array}{l}\text { As a whole, society is } \\
\text { slowly moving } \\
\text { towards a collective } \\
\text { consciousness, } \\
\text { brought about by } \\
\text { extensive knowledge } \\
\text { sharing and profound } \\
\text { empathetic } \\
\text { engagement. }\end{array}$ & $\begin{array}{l}\text { Infrastructure is } \\
\text { now fluid and } \\
\text { builds itself } \\
\text { according to human } \\
\text { needs. Food } \\
\text { nurtures social } \\
\text { relations and is also } \\
\text { an empathetic link } \\
\text { to the past, the } \\
\text { elders, and culture. }\end{array}$ & $\begin{array}{l}\text { Every person's opinion } \\
\text { matters and is heard, } \\
\text { no matter their age. } \\
\text { Every person has a } \\
\text { duty to serve the } \\
\text { community. } \\
\text { Art is a key medium } \\
\text { through which people } \\
\text { communicate with and } \\
\text { relate to one another. }\end{array}$ \\
\hline
\end{tabular}


Table 2. Differences in scenario characteristics based on Verge categories. The Verge framework assists in the exploration of how people experience their world.

\begin{tabular}{|c|c|c|c|c|}
\hline $\begin{array}{l}\text { Verge } \\
\text { categories }\end{array}$ & Rhiz(h)ome & Post Exodus & $\begin{array}{l}\text { Demos42 } \\
\text { Ubuntunse }\end{array}$ & Radical TransLocal \\
\hline $\begin{array}{l}\text { Define } \\
\text { (concepts, } \\
\text { ideas, } \\
\text { paradigms } \\
\text { used to } \\
\text { define } \\
\text { humanity } \\
\text { and the } \\
\text { world) }\end{array}$ & $\begin{array}{l}\text { Anti-utilitarian, } \\
\text { focused on human } \\
\text { well-being; } \\
\text { collaboration and } \\
\text { partnership (rather } \\
\text { than competition) are } \\
\text { a key ethic; awareness } \\
\text { of marginalized } \\
\text { people and the } \\
\text { environment; } \\
\text { empathy for } \\
\text { accommodating } \\
\text { differences }\end{array}$ & $\begin{array}{l}\text { People define } \\
\text { themselves as "post- } \\
\text { humans", i.e. those that } \\
\text { did not flee the planet } \\
\text { and had to start anew. } \\
\text { Post-humans are no } \\
\text { longer separate from } \\
\text { the Earth and from } \\
\text { nature, they see } \\
\text { themselves as part of a } \\
\text { greater cycle of life that } \\
\text { encompasses all living } \\
\text { things. }\end{array}$ & $\begin{array}{l}\text { Benign super- } \\
\text { intelligence, } \\
\text { Demos42, that } \\
\text { makes all } \\
\text { decision- } \\
\text { making } \\
\text { transparent }\end{array}$ & $\begin{array}{l}\text { Community-based whole- } \\
\text { person, intergenerational, } \\
\text { lifelong learning and } \\
\text { exchange of skills form the } \\
\text { basis of this worldview. } \\
\text { "Loverment"- is a } \\
\text { concept that integrates } \\
\text { governance and learning. } \\
\text { Government structures and } \\
\text { schools are inter-linked. }\end{array}$ \\
\hline $\begin{array}{l}\text { Relate } \\
\text { (social } \\
\text { structures } \\
\text { and } \\
\text { relationships) }\end{array}$ & $\begin{array}{l}\text { Citizen-led } \\
\text { governance by active, } \\
\text { knowledgeable } \\
\text { citizens that take } \\
\text { responsibility; strong } \\
\text { family structures and } \\
\text { values; inclusion of } \\
\text { deviance - not } \\
\text { excluding people }\end{array}$ & $\begin{array}{l}\text { Long lives mean long- } \\
\text { lived consequences - } \\
\text { all conflict is resolved } \\
\text { by means of deep } \\
\text { dialogue and } \\
\text { empathetic } \\
\text { engagement. }\end{array}$ & $\begin{array}{l}\text { Fluidity in } \\
\text { relations, e.g. } \\
\text { gender is fluid } \\
\text { and } \\
\text { infrastructure } \\
\text { is shape- } \\
\text { shifting. }\end{array}$ & $\begin{array}{l}\text { There are cities but they } \\
\text { are closely linked with } \\
\text { peri-urban villages. People } \\
\text { don't want to move much, } \\
\text { those that do, either do it } \\
\text { virtually or using our } \\
\text { advanced underground } \\
\text { transport system. Rituals } \\
\text { and art-making also } \\
\text { connect people. }\end{array}$ \\
\hline $\begin{array}{l}\text { Connect } \\
\text { (technologies } \\
\text { and practices } \\
\text { used to } \\
\text { connect } \\
\text { people, } \\
\text { places, and } \\
\text { things) }\end{array}$ & $\begin{array}{l}\text { People belong to } \\
\text { multiple, non- } \\
\text { geographically } \\
\text { constrained } \\
\text { communities linked } \\
\text { through the internet; } \\
\text { diverse languages } \\
\text { assisted by auto- } \\
\text { translation; } \\
\text { government provides } \\
\text { enabling and } \\
\text { decentralized } \\
\text { infrastructure that is } \\
\text { community owned } \\
\text { (e.g. internet, smart } \\
\text { electricity grid) }\end{array}$ & $\begin{array}{l}\text { The Collective allows } \\
\text { for local and global } \\
\text { connection, and a new, } \\
\text { shared language } \\
\text { enhances } \\
\text { communication. } \\
\text { Extensive know-ledge } \\
\text { sharing and empathetic } \\
\text { engagement is slowly } \\
\text { leading to the formation } \\
\text { of a collective } \\
\text { consciousness. }\end{array}$ & $\begin{array}{l}\text { Everyone is } \\
\text { connected } \\
\text { through } \\
\text { Demos42, but } \\
\text { there are } \\
\text { sacrosanct } \\
\text { places for } \\
\text { quiet } \\
\text { reconnection } \\
\text { to the self. }\end{array}$ & $\begin{array}{l}\text { Everyone is connected } \\
\text { through technology and } \\
\text { the socially conscious } \\
\text { VERITAS system, which } \\
\text { provides opportunities for } \\
\text { daily interactions between } \\
\text { citizens. } \\
\text { Yet natural spaces } \\
\text { represent important } \\
\text { gathering sites for } \\
\text { communities. }\end{array}$ \\
\hline $\begin{array}{l}\text { Create } \\
\text { (technology } \\
\text { and } \\
\text { processes } \\
\text { with which } \\
\text { goods and } \\
\text { services are } \\
\text { produced) }\end{array}$ & $\begin{array}{l}\text { Green Economy, } \\
\text { multi-purpose } \\
\text { technology that is } \\
\text { ecologically friendly; } \\
\text { 3D printing enables } \\
\text { local production; } \\
\text { green buildings; } \\
\text { urban, localized food } \\
\text { production greatly } \\
\text { reduces transport of } \\
\text { food }\end{array}$ & $\begin{array}{l}\text { Profound belief that } \\
\text { death and life are } \\
\text { circular and dependent } \\
\text { on one another - hence } \\
\text { all things are created to } \\
\text { be destroyed. }\end{array}$ & $\begin{array}{l}\text { Infrastructure } \\
\text { is need driven } \\
\text { and flexible to } \\
\text { respond to } \\
\text { needs. } \\
\text { Biomimicry is } \\
\text { central to } \\
\text { construction. }\end{array}$ & $\begin{array}{l}\text { Food is produced in the } \\
\text { iMeat } 3000 \text { machine, } \\
\text { installed in each household } \\
\text { to produce food through a } \\
\text { process of in-vitro } \\
\text { printing. Most inputs are } \\
\text { grown in } \\
\text { factories/production plants } \\
\text { and include protein made } \\
\text { by fly larvae, jelly fish, } \\
\text { and newly created forms of } \\
\text { protein. }\end{array}$ \\
\hline
\end{tabular}




\begin{tabular}{|c|c|c|c|c|}
\hline $\begin{array}{l}\text { Consume } \\
\text { (the ways in } \\
\text { which goods } \\
\text { and services } \\
\text { are acquired) }\end{array}$ & $\begin{array}{l}\text { Small businesses and } \\
\text { cooperatives } \\
\text { dominate; } \\
\text { subscription based } \\
\text { access to codes or } \\
\text { designs for goods; } \\
\text { much less exchange } \\
\text { of traditional fiat } \\
\text { currency; instead, } \\
\text { direct exchange of } \\
\text { diverse tokens, } \\
\text { reducing the crowding } \\
\text { out of diverse human } \\
\text { motivations and } \\
\text { changing the role and } \\
\text { meaning of money }\end{array}$ & $\begin{array}{l}\text { As in nature, nothing is } \\
\text { wasted, and the cycle of } \\
\text { production and } \\
\text { consumption is circular. } \\
\text { Diverse value exchange } \\
\text { systems exist - money } \\
\text { is not the only currency } \\
\text { in The Collective. }\end{array}$ & $\begin{array}{l}\text { Basic needs } \\
\text { are free, e.g. } \\
\text { gastro- } \\
\text { gardens } \\
\text { provide for } \\
\text { citizens' food } \\
\text { needs. As a } \\
\text { water stressed } \\
\text { region, water } \\
\text { is harvested } \\
\text { and saved } \\
\text { according to } \\
\text { seasonality. } \\
\text { Energy is } \\
\text { renewable and } \\
\text { community } \\
\text { owned, which } \\
\text { is made } \\
\text { possible by } \\
\text { 4D printing. }\end{array}$ & $\begin{array}{l}\text { VERITAS stands for } \\
\text { "Virtual Eco-centric } \\
\text { Redistributive Index Tax } \\
\text { Adaptive System" } \\
\text { People only produce what } \\
\text { they need, the rest is given } \\
\text { away as part of a gift } \\
\text { economy, or traded. The } \\
\text { gift/sharing economy } \\
\text { means that instead of } \\
\text { individual wealth, any } \\
\text { accumulated wealth is } \\
\text { spread around the } \\
\text { community. }\end{array}$ \\
\hline $\begin{array}{l}\text { Destroy } \\
\text { (the ways } \\
\text { and things } \\
\text { that are } \\
\text { demolished) }\end{array}$ & $\begin{array}{l}\text { Restoration and } \\
\text { rehabilitation are } \\
\text { multi-purpose; closed } \\
\text { loop systems; use, } \\
\text { recycle and minimize } \\
\text { waste; "ownership" of } \\
\text { the full production } \\
\text { and consumption } \\
\text { cycle }\end{array}$ & $\begin{array}{l}\text { No sickness due to } \\
\text { advanced gene therapy, } \\
\text { and no prisons due to } \\
\text { system of conflict } \\
\text { resolution through deep } \\
\text { dialogue. Anything that } \\
\text { is destroyed feeds back } \\
\text { into the cycle of } \\
\text { creation and } \\
\text { production. }\end{array}$ & $\begin{array}{l}\text { Demilitariza- } \\
\text { tion has } \\
\text { resulted in the } \\
\text { fall of the } \\
\text { nation state. } \\
\text { No borders, } \\
\text { no passports, } \\
\text { no more } \\
\text { multi- } \\
\text { nationals. }\end{array}$ & $\begin{array}{l}\text { A "living ethics" is } \\
\text { advocated - instead of } \\
\text { dealing with the } \\
\text { consequences of conflict, } \\
\text { the causes are dealt with } \\
\text { through a process of } \\
\text { dialogic engagement and } \\
\text { regulation taught to all } \\
\text { from a young age. }\end{array}$ \\
\hline
\end{tabular}

